\title{
REALANALYSE OG DEN MATERIALISTISKE \\ HISTORIEOPFATTELSE
}

\author{
Allan Andreassen, Flemming Bahner, Bo Elling, Søren \\ Kerndrup og Tyge Kjær
}

\section{Indledning}

Formålet med denne artikel er at diskutere mulighederne for udviklingen af en historisk aktuel marxisme, som tager udgangspunkt i Marx's videnskabelige resultater. En Marxisme, der derfor ikke mod eller med sin egen vilje går bag Marx, og dermed opgiver at nyttiggøre sig med de af hans videnskabelige resultater, som har gyldighed for den nuværende kapitalisme.

Disse diskussioner har to poler. Den ene pol er den materialistiske historieopfattelse og hvordan den aktuelle marxisme forholder sig til den. Med den materialistiske historieopfattelse mener vi præcist og bestemt ikke den historiske materialisme, som er en degenerering af den af Marx og Engels udarbejdede materialistiske historieopfattelse. For Marx og Engels var det et spørgsmål om at fremstille de virkelige materielle forhold udfra den historiske proces, hvorigennem de udvikles. Det kan ikke gøres udfra vilkårlige og i forvejen fikserede kategorier; det fører til spekulativ og filosofisk elendighed. Den historiske udvikling må selv levere de begreber, som de virkelige materielle forhold må fremstilles igennem. Den materialistiske historieopfattelse består derfor ikke af en række dogmer og abstrakte betragtninger om samfundets objektive udvikling. Det gør den historiske materialisme derimod; deraf degenereringen.

Diskussionernes anden pol er venstrefløjens marxismeopfattelse og realanalysediskussionerne. Det er især et spørgsmål om den rolle, som Marx's centrale værk - Kapitalen - har haft og stadig har for den ikkereformistiske 
venstrefløj. Vores hovedsynspunkt er, at Kapitalen i hovedsagen er blevet læst udelukkende logisk eller filosofisk - om man vil, og at denne læsetradition er i modstrid med den materialistiske historieopfattelse. De realanalysediskussioner og realanalysefors $\emptyset$ g, som udsprang af denne læsetradition, har da også udvist klare blokeringer over for undersøgelsen af de aktuelle, historiske forhold.

Vi fører altså en kritik frem af den logiske Kapitallæsningstradition, fordi den ikke har været i stand til at udvikle en historisk aktuel marxisme, som kan begribe og foregribe den aktuelle kapitalistiske udvikling. Vores formål er imidlertid ikke, hverken at udradere eller underkende de resultater, som er nået, men at diskutere en videreudvikling. Vores formål er under ingen omstændigheder at fremkomme med nye systemer eller formler for den korrekte marxisme.

I artiklen går vi frem på følgende måde: først giver vi en summarisk oversigt over marxismens udvikling herhjemme i 1960'erne og 1970'erne, som i stor udstrækning har formet sig som en kollektiv læreproces, for at påvise baggrunden for Kapitallæsningstraditionen; dernæst behandler vi det såkaldte rekonstruktionsprogram, de i perioden fremherskende Kapitallæsetraditioner og de hertil knyttede realanalysediskussioner (afsnit 2).

Dernæst uddyber vi den materialistiske historieopfattelse, dels udfra Marx' og Engels's opfattelse af sagen, og dels ved at diskutere forholdet mellem logik og historie eller teori og empiri, altsammen med det formål at forbinde realanalysen med den materialistiske historieopfattelse (afsnit 3).

Til sidst behandler vi realanalyseproblemerne, hvor vi tager udgangspunkt i forholdet mellem værdi og pris, og med nogle eksempler forsøger at vise, hvordan en materialistisk historisk rekonstruktion af marxismen må tage sig ud eller i hvert fald hvordan en materialistisk historisk rekonstruktion af Marx's Kapitalen kan gribes an, d.v.s. udviklingen af realanalyser indenfor rammerne af den materialistiske historieopfattelse (afsnit 4).

\section{Marxismen - genopdagelse og problemer}

De diskussioner, som føres i dag om marxismens funktion og mulige krise, har nogle historiske paralleller til diskussioner i 1930'erne. I 1931 skrev Karl Korsch, ${ }^{1}$ at »Marxismen som bevægelse og som teori befinder sig for tiden i

1. Krise des Marxismus, s. 167, i Karl Korsch: Die materialistischen Geschichtsauffassung und andere Schriften, Frankfurt a.M. 1971, s. 167-172. Korsch er ikke den eneste, som i denne peri- 
en krise. Det drejer sig her ikke blot om en krise indenfor marxismen, men om selve marxismens krise."

Korschs konstateringer og de grunde, han giver, kan på en række punkter siges at have en fortsat aktualitet. 1960'erne og 1970'erne har budt på en række fors $\varnothing \mathrm{g}$ på at genoptage og genetablere en marxisme, mere eller mindre med samme udgangspunkt som Korsch, men ingen af dem har i samme udstrækning som Korsch betonet den oprindelige og den overleverede marxistiske traditions historiske betingethed og en aktuel marxismes konkrete historiske bundethed. Korsch er følgelig langt mere radikal i sin kritik, både i forhold til datidens marxismetradition, men også i forhold til i dag. ${ }^{2}$ Hans synspunkter fra 1930'erne skal derfor refereres mere udførligt.

Marxismens krise, siger Korsch videre i den citerede artikel, skyldes ikke, at teorien er blevet degenereret af epigonerne, og dens krise overvindes følgelig heller ikke ved at insistere på Marx-Engels marxismens »rene lære«, fordi krisen er betinget af en krise i selve Marx-Engels teorien. Det viser sig gennem en afhistorisering eller historisk almengørelse, som betyder en opgivelse af den materialistiske historieopfattelse: »... Den ideologiske og doktrinære løsrivelse af den »rene lære« fra den virkelige historiske bevægelse, som udelukker teoriens videreudvikling, er i sig selv en fremtrædelsesform for marxismens bestående krise. $\ll^{3}$

Den aktuelle (d.v.s. 1930'ernes) marxisme har siden dens historiske udspring i sidste halvdel af det 19. århundrede haft en iboende adskillelse mellem teori og praksis. Gennem indoptagelse af bestemte, udvalgte elementer fra Marx-Engels teorien, som er fremstået på et helt andet historisk grundlag, var 1930'ernes marxisme en teori, der ikke var et alment udtryk for eksisterende klassekampe, snarere en sammenfatning af klassekampenes resultater fra en tidligere periode uden relationer til de nuværende klassekampe.

ode gjorde en sådan kritik gældende af marxismen. Af andre må nævnes Mattick og Rosdolsky, som han da også arbejdede sammen med efter emmigrationen til USA i 1936, bl.a. omkring det tidsskrift, Living Marxism, som Mattick redigerede. Medens Mattick havde en politisk baggrund i de hollandske rådskommunister, så havde Korsch sin baggrund i KPD’s venstrefløj, som i 1926 blev ekskluderet af partiet. Uanset forskellige politiske opfattelser, havde Korsch og Mattick den samme kritik af den overleverede marxisme. Det er den kritik, som vi her refererer til ved at citere Korsch.

2. Det bør nævnes, at Schanz, som med sin bog »Til rekonstruktionen af kritikken af den politiske $\varnothing$ konomis omfangslogiske status ( $̊$ rhus 1973) bidrog til rekonstruktions-diskussionerne her i landet, også behandler Korschs kritik af postmarxismen, og der tilslutter sig Korschs analyseintentioner, men uden nærmere begrundelser afviser Korschs analysemetode - ikke mindst fordi Schanz selv hævder tesen om epigonernes degenerering af marxismen som det afgørende, hvorimod Korsch afviser degenereringen som årsag til marxismens krise.

3. Krise des Marxismus, op. cit., s. 167. 
Adskillelsen mellem teori og praksis er i udviklingsforløbet ikke blevet svækket, men skærpet.

På dette grundlag fremstod der - stadig ifølge Karl Korsch - tre ejendommelige teoretiske retninger: dels reformismen, dels ortodoksien, og dels en retning, der ville genfremstille den oprindelige revolutionære marxisme i ren form. ${ }^{4}$

Disse retningers udvikling hang sammen med den måde, hvorpå den europæiske arbejderbevægelse i sidste halvdelen af det 19. århundrede havde opfattet og indoptaget den marxistiske teori. Her nævner Korsch to områder af betydning:

Den materialistiske historieopfattelse fremstod i den revolutionære periode før 1850 som en umiddelbar bestanddel af den revolutionære klasses subjektive aktion, men den blev forvandlet til en kun abstrakt, anskuende teori om den samfundsmæssige udviklings objektive forløb (under betegnelsen historisk materialisme).

Kritikken af den politiske фkonomi var - af Marx - oprindelig udarbejdet som en radikal kritik af den borgerlige klasses politiske økonomi. I dag (d.v.s. i 1930'erne) forstår såvel apologeterne som kritikerne den 'Marxistiske $\varnothing$ konomi' som et videnskabeligt system, hvorfra der forsøges en teoretisk afledning af alle det borgerlige samfunds $\varnothing$ konomiske fremtrædelser udfra det ukritisk antagede, aksiomatiserede grundbegreb: »værdi «.

Korschs formål med kritikken, som han både tidligere har formuleret, men især senere genoptager og uddyber, ${ }^{5}$ er et fors $\emptyset$ gå at udvikle det, som han selv karakteriserer som en udogmatisk, historisk og kritisk, levende revolutionær marxisme. Hans kritik etableres primært gennem en historisk kritik - ved, som han siger, at anvende den materialistiske historieopfattelse på den materialistiske historieopfattelse selv. Afsluttende i artiklen om marxismens krise siger Korsch, at den marxisme, som historisk fremstod i første halvdel af det

4. Efter alt at dømme er den danske udvikling ikke tilnærmelsesvis parallel med den daværende tyske, omend den danske udvikling om noget er påvirket af den tyske marxismes udvikling (både som bevægelse og teori). Ortodoksien var udpræget for 1920-30'ernes danske DKP; reformismen (i den her givne teoretiske betydning) blev i hovedsagen udviklet af den socialdemokratisk partiorganiserede »Karl Marx Klub« (Bang, m.fl.), hvis betydning dog ikke kan sammenlignes med den Kautsky, Hilferding m.fl. havde for det tyske socialdemokrati; senere herhjemme i 1940'erne og 1950'erne blev reformismen, især dens økonomiopfattelse overtaget af DKP (Grünbaum, Svendsen f.eks.). Kautsky, Hilferding, m.fl. havde en dominerende stilling i langt de fleste europæiske socialdemokratier i 1920-30'erne; deres betydning kan især på det teoretiske plan spores herhjemme.

5. Af lignende Korsch-kritikker bør nævnes: Marxismus und Philosophie (1923); Der Geschichtsliche Charakter der marxistischen Wissenschaft (1925); Die Materialistische Geschichtauffassung (1929); Marxism and the Present Task of the Proletarian Class Struggle (1938); Karl Marx (1936-1947); 10 teser om marxismen i dag (o. 1950). 
19. århundrede, og som blev omdannet i anden halvdel af det 19. århundrede til en revolutionær ideologi af en arbejderbevægelse, som ikke længere var en revolutionær bevægelse, tilhører fortiden. Senere formulerer Korsch det endnu skarpere: »Alle fors $\emptyset \mathrm{g}$ på at genetablere den marxistiske lære som helhed i dens oprindelige funktion for arbejderklassens sociale revolution er i dag reaktionære utopier. $\ll^{6}$

Det kunne se ud som om Korsch er parat til at opgive marxismen; men det er ikke tilfældet. Det er umuligheden af at bygge på den historiske deformerede marxisme og umuligheden af at genskabe marxismens oprindelige funktion, det drejer sig om. Korschs kritik kan nemlig ikke forstås derhen, at der er tale om en fornægtelse af f.eks. Marx's videnskabelige resultater. I en artikel fra slutningen af 1930'erne siger Korsch således: ${ }^{7}{ }^{\prime}$ Man bør forstå, at hele den oven for rejste kritik [som har mange lighedspunkter med den her gengivede] udelukkende vedrører de sidste 50 års ideologiske bestræbelser på - med henblik på umiddelbar anvendelse - at »bevare « eller »restaurere « et helt igennem mystificeret »revolutionær marxistisk doktrin«. Intet i denne artikel er rettet imod de videnskabelige resultater, som Marx og Engels og nogle få af deres tilhængere nåede på de forskellige af samfundsforskningens områder, og som på mange måder holder stik den dag i dag. $\ll^{8}$

For Korsch drejer det sig tydeligvis om udviklingen af en forståelse af det bestående kapitalistiske samfunds virkelige bevægelses- og udviklingslove, som samtidig er de virkelige betingelser for den revolutionære, proletariske klasseaktion. ${ }^{9}$

6. Tese nr. 2 i: 10 teser om marxismen i dag; $i$ : Karl Korsch: Staten og kontrarevolutionen, Kbh. 1973, s. 251-252.

7. Marxismen og den proletariske klassekamps nuvarende opgave, s. 111; i: Karl Korsch: Staten og kontrarevolutionen, op. cit., s. 104-111.

8. I bogen Karl Marx sammenfatter Korsch Marx's vigtigste bidrag til samfundsforskningen i fem punkter (som vi dog ikke uden videre er enige i), nemlig, at Marx: 1. førte alle fremtrædelserne for de samfundsmæssige livsprocesser tilbage til økonomien; 2. også opfattede $\emptyset$ konomien som samfundsmæssig; 3 . bestemte alle samfundsmæssige fremtrædelser historisk og det som en revolutionær udvikling, hvis objektive grundlag består i udviklingen af menneskenes materielle produktivkræfter og hvis subjektive bærer er den samfundsmæssige klasse. Heri er indeholdt vigtige delresultater som: 4. den nøje bestemmelse af forholdet mellem $\emptyset$ konomi og politik, og 5. tilbageføringen af alle såkaldte »åndelige « fremtrædelser til samfundsmæssige bevidsthedsformer. jvf. Karl Korsch: Karl Marx, Frankfurt a.M. 1969, s. 203.

9. Om Korsch og hans kritik må det dog siges, at det især drejer sig om at påpege de dele af Marx's teori, som er faldet ud og har befordret en transformation af marxismen. Der er tale om programmatiske erklæringer, som ikke indeholder fors $\emptyset \mathrm{g}$ eller eksakte angivelser på, hvordan sagen må gribes an, selvom der dog findes formuleret ledetråde såsom: Marx’s materialistiske videnskab er en strengt empirisk undersøgelse af bestemte samfundsformer; den behøver ingen filosofi. 
Korschs kritik af 1930'ernes (og for den sags skyld også 1940'ernes og 1950'ernes) marxisme er også aktuel i dag, men grundlaget for marxismens betydning og placering som bevægelse og teori er et andet i dag end i den periode, som Korsch betragtede. Den foranførte analyse og kritik af marxismen kan således ikke direkte overtages.

\subsection{Marxismen på universiteterne i 1960-70'erne: dens genoptagelse og oprindelse}

Den eller de marxistiske traditioner er som bekendt rundt i Europa blevet genoptaget af studenterbevægelsen i 1960'erne og 1970'erne, og senere udviklet af en mere eller mindre homogen venstrefløj, som i vidt forkellig omfang fra land til land har haft mulighed for at manifestere sig politisk.

Selvom studenterbevægelsens marxisme-opfattelse herhjemme i begyndelsen var vidt forskellig fra den marxisme, som venstrefløjen senere har udviklet, så er der i hele perioden i al nævneværdighed tale om en teoretisk bevægelse. Det er selvklart: det var og er på universiteterne, at marxismen blev genopdaget og udviklet på ny, og ikke i arbejderbevægelsen.

Hovedlinierne i udviklingsforløbet i den første del af den periode, hvor interessen for marxismen vokser frem på universiteterne skal kort ridses op, fordi det klart viser, hvilke problemer den aktuelle marxisme står i idag. Her må nødvendigvis indskydes, at studenterbevægelsens teoretiske udviklingsforløb naturligvis var så mangfoldige, at disse hovedlinier kun må opfattes som visse almene holdepunkter i udviklingen, og ikke som en sammenfatning af alle tendenser i perioden. Vi skal kun nævne tyngdepunkterne i 1960'ernes og 1970'ernes studenterbevægelses kollektive erfaringsproces.

Indholdsmæssigt var 1960'ernes studenterbevægelse starten på et kritisk opgør med de borgerlige videnskabers indhold og funktion. Dette opg $ø r$ tog sin begyndelse i den abstrakte negation af de forhåndenværende videnskabelige discipliners teorier og metoder. Mediet for denne videnskabskritik blev videnskabsteorien, som blev forstået og anvendt som en abstrakt, universiel teori som et almen gyldigt kritikredskab.

Under det videre udviklingsforl $\varnothing \mathrm{b}$ hentede videnskabskritikken støtte i marxismen, men vel og mærke i de historiske rester af 1930'ernes marxisme, især hentet og udviklet indenfor to skarpt adskilte områder - filosofi og økonomi - gennem læsning af værker fra denne periode, men især ved læsning af nyere reproduktioner af 1930'ernes marxisme. 
Den marxistiske filosofi (eller marxistiske videnskabsteori, som den blev kaldt), blev som et abstrakt læresystem hentet dels fra dele af frankfurterskolen (Marcuse, Habermas, m.fl.), og dels - udformet i disciplinerne dialektisk materialisme og historisk materialisme - hentet fra de øst- og vesteuropæiske kommunistpartiers teoretikere (særlig vigtig for diskussionerne var Althusser fra det franske kommunistparti; Stalin og Lenin sammen med en række nyere $\varnothing$ øteuropæiske dialektiskmaterialisme-teoretikere).

Den marxistiske $\phi$ konomi blev opfattet som et læresystem med almene grundprincipper, og blev især hentet fra de angelsaksiske reproduktioner og videreudviklinger af 1930'ernes reformistiske økonomiopfattelse, hvor den politiske $\varnothing$ konomi blev opfattet i positiv forstand, nemlig med et bortamputeret kritikbegreb; (Marx opfattet som økonom). På denne økonomiopfattelses grundlag blev klasseteori, imperialismeteori, monopolteori, m.v. fors $\emptyset \mathrm{gt}$ formuleret (Fra Sweezy, Dobb, m.fl.; men også Mandel; det danske bidrag af Isi Grünbaum ikke at forglemme; hertil kommer Lenins imperialismeteori, som også spillede en rolle i udviklingen af økonomiopfattelsen og opfattelsen af kapitalismens udvikling og karakter).

Det var for såvidt et 'logisk' skridt, studenterbevægelsen foretog for at videreudvikle kritikken af de borgerlige videnskaber, nemlig at forlade videnskabsteorien i almindelighed som kritikredskab efterhånden som dens kritikpotentialer viste sig at være uden indholdsmæssig gyldighed, og tage fat på en marxisme, som kunne formuleres som et nyt og mere indholdsorienteret kritikredskab af de borgerlige videnskaber. Marxismen havde erstattet videnskabsteorien, men funktionen var den samme, nemlig at levere en kritik af fagene. Det var derfor ikke nogen tilfældighed, at de var de historiske rester af 1930'ernes marxisme, som studenterbevægelsen tog op i videreudviklingen af den kollektive erfaringsproces. Som et alment læresystem havde den de nødvendige egenskaber.

Marxismen som videnskabskritik tog efterhånden form af en mere selvstændig marxistisk teoretisk tradition sideløbende med udbredelsen af kendskabet til 1930'er-marxismen, men den kunne ikke hæve sig op over arvens mangler. Det blev en marxistisk tradition, som reflekterede, men kun abstakt kunne forholde sig til den nedarvede adskillelse mellem teori og praksis; en tradition som gennem en række doktriner var transformeret til livsanskuelse, filosofi, d.v.s. én i det højeste anskuende materialisme; samt en tradition som stadfæstede en marxisme, der indholdsmæssigt savnede enhver forbindelse med de aktuelle historiske forhold, altså en ahistorisk marxisme i skarp modstrid med den materialistiske historieopfattelse.

I og med at udgangspunktet var en kritik, som relativt snævert var rettet imod de borgerlige videnskabers enkeltdiscipliner, så blev kritikkens 
indholsmæssige konsekvenser et krav om udviklingen af alternative discipliner, som dog i praksis hurtigt viste sig at fungere som moderniseringstendenser af de borgerlige videnskaber, både på det snævre disciplinære niveau, såsom: marxistisk psykologi, marxistisk økonomi, marxistisk sociologi, marxistisk litteraturkritik, o.s.v.; men også på et generelt niveau som udvikling af en marxistisk forskning, hvor det borgerlige videnskabsbegreb på én og samme tid blev fastholdt og kvalificeret til trods for, at begreberne og metoderne var intenderet »marxistiske «.

Sammenfattende: den videnskabsteoretiske kritik, som havde påvist de borgerlige enkeltvidenskabers totalt manglende reflektioner over eget grundlag og funktion, førte til en ideologisk kritik af de borgerlige enkeltvidenskaber; da indsigten i de borgerlige videnskabers ideologiske grundlag og praktiske funktioner var nået, kunne intet føres videre ad denne vej. Den efterfølgende marxistisk baserede videnskabskritik førte til krav om alternative enkeltvidenskaber, som dårligt nok var proklameret førend kravet opløste sig selv. Fra denne periode stammer begrebet fagkritik, som havde til formål at udvikle nye discipliner eller ny faglighed på basis af videnskabskritikken. ${ }^{10}$

I det Øjeblik doktrinerne fra 1930'ernes marxisme var tilegnet, blev det også mere eller mindre hurtigt åbenlyst, at den reproducerede, historisk nedarvede marxisme intet kunne udrette; den kunne ikke andet end forblive et normativt, d.v.s. et standpunktserklærende standpunkt, og fra dette abstrakt erklærde standpunkt en amputeret kritik af de borgerlige videnskabsdiscipliner og af det borgerlige samfund.

10. Med fagkritik kan der i det mindste forstås to ting: fagkritik som metode, d.v.s. de borgerlige teorier og forestillinger som udgangspunkt for unders $\emptyset$ gelserne; og fagkritik som resultat, d.v.s. de borgerlige teorier og forestillinger fremstillet udfra deres materielle grundlag som resultat. I studenterbevægelsens fagkritiske periode blev fagkritikken proklameret som en metode, idet fagkritikken primært drejede sig om etableringen af en alternativ studiepraksis på eksisterende grundlag. Med udgangspunkt i enten de borgerlige teorier og forestillinger (intern fagkritik) eller i teoriernes praktiske funktion (extern fagkritik) drejede det sig om gennem kritikken at nå frem til en fremstilling af den virkelighed, som teorierne og deres funktion afspejlede. De materielle forhold skulle fremstilles gennem teorikritik; da en sådan kritik ikke kunne funderes materielt, måtte den funderes i den rette filosofi, som enten blev den marxistiske filosofi eller abstrakt erklærede arbejderinteresser. Fagkritik som metode antog en ukritisk metodisk parallelitet til Marx’s kritik af de klassiske økonomer (Ricardo især), på basis af hvilken Marx skulle have opdaget værdiloven. Den metodiske parallelitet er ikke holdbar, om ikke andet så fordi dagens borgerlige $\varnothing$ konomer f.eks. ikke er nogen Ricardo. Vi vender tilbage til problemstillingen om fagkritikken. 


\subsection{Karl Marx og hans Kapital på universiteterne i 1970'erne}

Fra dette udgangspunkt eller slutpunkt tager den teoretiske udvikling en ny retning, nemlig som forsøg på en rekonstruktion af især Marx's teoretiske resultater. Dette skete primært i form af en systematisk læsning af Kapitalen (og senere Grundrids, Resultater af den umiddelbare produktionsproces, Theorien über den Mehrwert, m.v.).

Der er ingen tvivl om, at en tilbagevenden til kilderne, d.v.s. til Marx's videnskabelige værker, var et nødvendigt udviklingstrin, dels for at overvinde opfattelsen af marxismen som en række læresætninger eller doktriner, og dels for at genopdage Marx's videnskabelige resultater, som den nedarvede marxisme åbenlyst havde undertrykt. Særlig vigtigt var vardiloven som en fremstilling af det kapitalistiske samfunds udbytningsform og -grundlag. Den var vigtig ikke mindst fordi den reformistiske $\varnothing$ konomiopfattelse havde udslettet den, og dermed skaffet sig af med det vigtigste argument for kapitalismens afskaffelse.

Det teoretiske rekonstruktionsprogram hentede Kapital-læsevejledning hos dels en yngre del af frankfurterskolen (Reichelt, Schmidt, m.fl.) og dels hos enkeltstående forfattere (Rosdolsky især, men også Mattick, Zeleny og en lang række andre) og ikke at forglemme forkortede udgaver af Kapitalen. ${ }^{11}$

Denne tilbagevenden til Marx's videnskabelige resultater var imidlertid ikke uden problemer. I kraft af den fremherskende marxismetradition kunne en sådan tilbagevenden indeholde en risiko for en "genopdagelse « af den rene logik; denne vej havde Althusser allerede anvist med sin symptomale kapitallæsning. ${ }^{12}$ Periodens teoretiske udvikling har da også indeholdt ten-

11. Marx’s videnskabelige hovedværk Kapitalen blev læst påny, nu ikke af arbejderbevægelsen, men på universiteterne. Den var stort set gået i glemmebogen kort efter den udkom. I 1880'erne havde herhjemme Socialdemokratisk Forbund udgivet bd. I og II på dansk; ca. 30 år senere udgav Gustav Bang en meget forkortet genfortælling af alle tre bind, hvor især tredie binds indhold var forvandsket (bogen er genudgivet - Gustav Bang: Den kapitalistiske $\varnothing$ konomi). Siden da ophørte al interesse for Kapitalen i den danske arbejderbevægelse. Marx havde aldrig været den danske arbejderbevægelses ubestridte teoretikere; Lasalle spillede en mindst ligeså stor om ikke større rolle, som senere overtoges af de tyske reformister. Som følge af den voksende interesse for Kapitalen blev den udgivet påny herhjemme i begyndelsen af 1970'erne. Paradoksalt nok var den oversættelse præget af reformismens økonomiopfattelse med en række »forbedringer« til følge. Jvf. kritikken heraf i: I anledning af Grundridsudgivelsen; Kurasje nr. 10, s. 104-120.

12. Jvf. L. Althusser og E. Balibar: Att Läsa Kapitalet, Bd. 1 og 2, Stockholm 1970, som anbefalede at læse Kapitalen filosofisk, helt i overensstemmelse med ortodoksiens tradition. Jvf. her Lenins bemærkning om, at hvis Marx ikke efterlod en logik med store bogstaver, så efterlod han dog logikken i Kapitalen, som han anbefaler uddraget og anvendt; V. I. Lenin: Philosophical Notebooks, Collected Works, Moskva 1963, Vol. 38, s. 319. 
denser, hvorefter rekonstruktionsprogrammet ikke blev opfattet som en etablering af en historisk aktuel og kritisk marxisme, men snarere en genopdagelse af noget »oprindeligt« i Marx’s værker, som Marx måske ikke engang selv kendte til. Der forekom således tilløb til, at Kapitalen blev læst udfra en utilfredshed med 1930'er-marxismens svar på, hvad marxismen var, men med en samtidig accept af 1930'er-marxismens problemstilling: den autentiske marxisme og dens læresætninger. En sådan tendens strider naturligvis klart mod en materialistisk historieopfattelse; det vender vi tilbage til.

1970'ernes rekonstruktionsprogram gennem læsningen af Kapitalen og de diskussioner, som denne retning - eller rettere retninger, da der vitterligt var og er tale om flere retninger - har affødt, har især været koncentreret omkring to hovedspørgsmål, nemlig for det første hvordan Kapitalen skulle opfattes, d.v.s. en diskussion af, hvori det specifikke og det i teorihistoriske sammenhænge nye i Marx's videnskabelige resultater bestod; og for det andet med st $\varnothing$ tte heri en formulering af, hvordan teoriens konkrete formidling skulle behandles.

Rekonstruktionsprogrammet blev især af de afstandstagende kritikere positivt afgrænset som den kapitallogiske skole. Det var ærefuldt, at en systematisk læsning af Kapitalen fremfor løsrevne citat- og kapitallæsninger og læsning af værker om læsning af Kapitalen af kritikerne kunne identificeres som en 'skole'; det var samtidigt futilt. Den væsentligste del af den form for kritik kom fra folk, der hævdede den ortodokse marxismefilosofi eller den reformistiske økonomiteori, som altså stod på 1930'er-marxismeopfattelsen, som netop Kapitallæsningen og rekonstruktionsprogrammet var en overskridelse af. ${ }^{13}$

Der blev imidlertid også rettet en kritik mod rekonstruktionsprogrammet indefra, d.v.s. fra standpunkter, som fastholdt intentionerne med udviklingen af en historisk aktuel marxisme med baggrund i Marx's videnskabelige resultater, men som samtidig anså rekonstruktionsprogrammet for at være ufuldstændigt; det kunne ikke bryde radikalt nok med den overleverede, eksegetiske marxismetradition på den ene side, og på den anden side kunne programmet ikke indfri intentionerne om en historisk aktualisering af marxismen. Det var især et spørgsmål om, hvilken status de almene bestemmelser skulle have overfor historien: hvad var givet gennem logikken og hvad var givet gennem den historiske udvikling?

I kraft af rekonstruktionsprogrammets Kapitallæsning blev det centrale et spørgsmål om sammenhængen mellem opfattelsen af Kapitalen og det

13. Jvf. f.eks. H. Andersen, m.fl.: Kritik af kapitallogikken, Demos, 1975, som konsekvent nok (i forhold til eget standpunkt) mere var en kritik af Marx og alle hans såkaldte fejltagelser end en karakteristik og kritik af rekonstruktionsprogrammet; et typisk udslag af den reformistiske kritiktradition. 
empiriske. Hvordan skulle Kapitalen opfattes, og hvordan kunne det empiriske problem fastlægges, så det ikke førte til skinempiri. De løsninger, som blev søgt på dette spørgsmål kan illustreres med to forskellige rekonstruktionstendenser, som begge giver et karakteristisk billed af periodens diskussioner, ikke mindst fordi deres primære ophavsmænd har gjort sig kraftig gældende i periodens diskussioner.

Første eksempel: ihvorvel H. J. Schanz's rekonstruktionsprogram sigter på at udvikle og præcisere kritikken af den politiske økonomi i en sådan retning, at realanalysen (undersøgelse af det specifikke i dets historiske konkretion) kan gennemføres, så fører hans opfattelse af Kapitalen til en udpræget empiri/historie-impotens. Hans undersøgelser kan sammenfattes i - eller er $\mathrm{i}$ det mindste blevet sammenfattet $\mathrm{i}$ følgende citat: ${ }^{14} \gg \ldots$ en reflektion [indenfor selve Marx's Kapitalen] med følgende tre momenter: das Kapital im Allgemeinen (det formbestemmende for alle værdielementer og deres udviklingsformer i en kapitalistisk produktionsmåde), das Kapital in seiner Realität im Allgemeinen (de almene bestemmelser for enkeltkapitaler, deres forhold til hinanden under den kapitalistiske produktionsmådes udvikling, behandles i Kapitalbind III efter transformationen af merværdiformen til profitformen) og endelig das Kapital in seiner Realität (bestemmelser, som er afgørende for den enkelte kapitals historiske og samfundsmæssige specificitet, hvor dette forhold ikke længere består udelukkende af rene og hypostaserbare værdiformsdeterminatorer). Undersøgelsen af das Kapital in seiner Realität findes ikke hos Marx, og kan i sagens natur heller ikke findes der, da dette 'lag' netop ikke kan fremstilles i almindelighed, eftersom realobjektet på dette plan ikke længere foreligger i almindelighed: Danfoss' faktiske og specifikke økonomiske aktivitetsudfoldelse kan ikke afledes af kapitalen $\mathrm{i}$ en eller anden Allgemeinheit, her er empiriske undersøgelser uomgængelige.«

Det Schanzske system fuldstændiggøres med et kapitalexternt niveau, nemlig de subsumtive interventionsformer, som er områder der ikke direkte er underlagt værdiformsbestemmelser. ${ }^{15}$ Det er i sagens natur ikke muligt at udvikle en almengyldig teori for de subsumtive interventionsformer, fordi disse former altid vil være historisk specifikke. Sammen med niveauet 'kapitalen i dens realitet' udgør de subsumtive interventionsformer derfor det empiriske niveau, omend af forskellig art.

14. Hans-Jørgen Schanz: Til rekonstruktion af kritikken af den politiske $\emptyset$ konomis omfangslogiske status; Århus 1973, s. 136 (vores fremhævelser).

15. Jvf. H. J. Schanz, op.cit., s. 182-187. 
Schanz's opfattelse af Marx's Kapitalen kan sammenfattes således: i Kapitalen fremstilles værdiens (eller kapitalens) subsumtionsformers rene udvikling, begyndende med de mest almene, som opfattes som rammebetemmelser for de næstfølgende niveauer eller momenter, for at ende med de specifikke. I umiddelbar tilknytning hertil opereres der med et område, der ikke direkte er subsumeret værdien (eller kapitalen), især på grund af dets materialitetsform. På denne måde forstås Marx's Kapitalen som en deduktiv bevaegelse fra det almene til det specifikke, hvor det empiriske fastlægges som det næstsidste og sidste led. Efter Schanz vil en realanalyse derfor begynde med det næstsidste led (kapitalen i dens realitet), forudsat de nødvendige forudgående almene bestemmelser, hvor en specifik kapitals bevægelse eller kapitalens specifikke bevægelse kan unders $\varnothing$ ges. Efterfølgende kan det sidste moment tilføjes, f.eks. den konkrete klassekampssituation, som Schanz regner med til de subsumtive interventionsformer. ${ }^{16}$

Den opfattelse af Kapitalen strider imod de angivelser, som Marx selv giver i Kapitalen vedrørende den anvendte abstraktionsprocedure. ${ }^{17}$ Analysens logiske gang i Kapitalen er nemlig tydeligvis således: først studeres produktionen som sådan, d.v.s. der abstraheres fra cirkulationen, forstået på den måde, at en systematisk behandling af cirkulationen ikke indgår, - omvendt forudsættes den (jvf. om ikke andet så undertitlen på første bog: kapitalens produktionsproces); dernæst studeres cirkulationen (jvf. undertitlen på anden bog: kapitalens cirkulationsproces); slutteligt studeres produktion og cirkulation som et hele (jvf. undertitlen på tredie bog: den kapitalistiske produktionsproces som et hele).

Fastholdes det, at der er tale om en abstraktionsprocedure, hvor der gennem fremstillingen fra første (og anden) til tredie bog inddrages flere og flere bestemmelser, hvad der omvendt svarer til, at abstraktionerne udtyndes trin for trin, så er der - som hos Schanz - ikke grundlag for at opfatte Kapitalen som en deduktiv fremstilling. Kapitalen kan ikke opfattes som en fremstilling af værdiformens subsumtionslogik; det forudsætter, at man helt ser bort

16. På denne baggrund kan det naturligvis ikke undre, at den almene kritik, som generelt blev rettet mod »kapitallogikken«, var, at den ikke var i stand til at inddrage arbejderklassens aktioner endsige klassekampen. Det var rigtigt i samme udstrækning det var rigtigt, at det schanzske system heller ikke kunne forholde sig til øvrige dele af den umiddelbart foreliggende virkelighed. For at bøde på dette har en række folk indenfor Schanz-traditionen fors øgt sig med hjælpekonstruktioner, især knyttet til de såkaldte materialitetsformer (dobbeltlogik, f.eks.).

17. I Grundrids, hvorfra Schanz henter sine tre momenter eller niveauer, opererer Marx med forskellige abstraktionsniveauer, nemlig kapital $i$ almenhed modstillet de mange kapitaler, og adskilt herfra kapitalen $i$ dens realitet, som dog ikke findes identisk i Kapitalen, og som her på ingen måde bindes deduktivt sammen som hos Schanz. Jvf. undersøgelsen af forholdet mellem Grundrids og Kapitalen hos Roman Rosdolsky: Kapitalen i almenhed og de mange kapitaler, Kurasje nr. 7, s. 66-76, især s. 73-76. 
fra det faktisk forekommende historiske materiale i Kapitalen, eller betragter det som rent illustration uden betydning. På et hvilket som helst abstraktionstrin er der i Kapitalen tale om realbegreber, forstået enten som foregribelser eller sammenfatning af en historisk proces. ${ }^{18}$ Følgelig kan det ikke hævdes, at et bestemt niveau (som Schanz) er det empiriske niveau. Værdiernes fremtrædelse i prisformen og de bevægelser, som historisk følger heraf (f.eks. tendenser til dannelse af en gennemsnitsprofitrate) kan selvklart ikke studeres empirisk uden at inddrage cirkulationen, og forudsætter altså inddragelsen af bestemmelserne i tredie bog; modsat kan f.eks. akkumulationsprocessens aktuelle historiske udviklingsforløb naturligvis studeres udfra bestemmelserne fra første bog uden en systematisk inddragelse af bestemmelserne $i$ anden og tredie bog.

Det Schanzske system befordrer den opfattelse, at de empiriske undersøgelser betår i, at projicere de almene bestemmelser ud i det empiriske materiale, som derfor underst $\varnothing$ tter den unders $\emptyset$ gelsesstrategi, hvor efter de almene bestemmelser (gen)udarbejdes til et bestemt og tilstrækkeligt niveau, førend de empiriske undersøgelser kan påbegyndes. Det er det samme som, at logikken må udarbejdes og udarbejdes samlet til en bestemt detaljeringsgrad førend historien kan inddrages.

De empiriske undersøgelser fastlægges følgeligt som et projektionsspørgsmål, og i sin mere ufærdige form som et eksemplifikationsspørgsmål, og ikke som et spørgsmål om sammenfatning af de umiddelbare fremtrædelser, og derfor ikke som et spørgsmål om at sætte fremtrædelserne på deres rette, d.v.s. deres virkelige begreb, men at formidle teorien gennem det konkrete stof, d.v.s. sætte begreberne på deres »rette« fremtrædelser.

Rekonstruktionsprogrammet gennem læsningen af Kapitalen var ikke kun knyttet til Schanz opfattelse af Kapitalen. Perioden præges af en lang række, også mere konkret-historisk orienterede rekonstruktionsfors $\varnothing \mathrm{g}$. Disse fors $\varnothing \mathrm{g}$ kan sammenfattes med betegnelsen afledningsstrategien, som især kom til at præge to vidt forskellige undersøgelsesområder, dels bevidsthedsformer og dels statsteorien. Hovedproblemet bestod i, på hvilket abstraktionsniveau i Kapitalen skulle statsteorien henholdsvis bevidsthedsteorien indpasses. Skulle teorierne knytte an til de almene bestemmelser eller de mere specifikke bestemmelser; skulle det være bind I's eller bind III's niveau? Afledningsstrategien, ikke mindst i dens forfladigede former, var tydeligvis indfanget $\mathrm{i}$

18. I et brev til Engels, hvor Marx redegør for opbygningsplanerne af Kapitalen, skriver han: »De mest abstrakte bestemmelser, nøjere undersøgt, viser altid hen til en mere konkret bestemt historisk basis. (Naturligvis, da de i denne bestemthed er abstraheret derfra.)« Marx an Engels, 2. april 1858, MEW bd. 29, s. 317. 
de samme problemer som Schanz's rekonstruktionsprogram, nemlig problemet med at fastlægge det niveau, hvorfra virkelighedens historiske former mere eller mindre deduktivt kunne fremstilles.

Andet eksempel: i Altvaters statsanalyseartikel fra 1972 (publiceret herhjemme i 1973), som ironisk nok gav anledning til en statsteori-»afledningsbølge « herhjemme og i Vesttyskland, tales der om en tosporet fremgangsmåde i forholdet mellem logik og historie: ${ }^{19} \gg \ldots$ tilegnelsen af Marx's fremstilling af kapitalbegrebets logiske struktur og analyse af kapitalismens konkrete historiske fremtrædelser - må på ingen måde opfattes som et metodisk postulat. Der findes iøvrigt ingen kongevej fra det almene kapitalbegreb til kapitalforholdets overflade og et konkret samfunds historiske udviklingsforløb.«

Altvater siger videre, at man ikke kan vente med analysen af konkrete problemer til, man har nået det punkt, hvor teorien endelig slår om i metode, ikke mindst fordi et sådant punkt ikke findes, og fordi opsøgningen af et sådant punkt vil føre til »de kategoriale udledningers uendelighed. ${ }^{20}$

For Schanz var analysens holdepunkt en rekonstrueret tilegnelse af Kapitalen, dernæst en omfangskarakteristik af det empiriske. Altvaters udgangspunkt er den konkrete historiske analyse med et teoretisk holdepunkt i den marxske teori. Rekonstruktion af den marxske teori er der næppe tale om hos Altvater, men tilegnelsen af den underkendes ikke, idet han siger: ${ }^{21} » \ldots$ tilegnelsen af den marxske teori [er] ubetinget nødvendig, ikke som et instrument, der må læres f $\phi r$ man beskæftiger sig med problemerne i den virkelige bevægelse og teori, og heller ikke som et dogme, der stadig må udlægges »ex cathedra«, men derimod som en begrebslig abstraktion af kapitalforholdets virkelige bevægelse, som med kapitalismens udvikling fremtvinger nye spørgsmål, [...] denne »realanalyse « omfatter både væsensanalysen og analysen af fremtrædelsesformerne (både i deres systematiske begrebslige udledning og i deres konkrete historiske forløb).«

Bruges Altvaters formuleringer mod det Schanzske system kan man sige, at H. J. Schanz med det citerede værk forsøger at fastlægge 'kongevejen' og gennem kategoriale udledninger at nå frem til det punkt, hvor teorien på mystisk vis slår om i metode; kritikken er også parat: det fører til udledningernes uendelighed. Altvater har fået ret i denne kritik, hvad en stor del af periodens teoretiske arbejder viser; her forekommer der tendenser i den retning, både hos

19. E. Altvater: Om nogle problemer ved statsinterventionismen, Kurasje nr. 7, s. 24-25.

20. E. Altvater, op.cit., s. 25.

21. E. Altvater, op.cit., s. 24. 
de bidrag, der har været befordret af det schanzske system, men også hos de bidrag, der ad andre veje, f.eks. gennem afledningsstrategien, har søgt at indfri rekonstruktionsprogrammet.

Altvaters tosporede undersøgelsesprogram, som senere blev udbygget gennem en undersøgelse af akkumulationsudviklingen i Vesttyskland, ${ }^{22}$ rejste to hovedproblemstillinger: dels vedrørende de almene begrebers eller den marxske teoris status, og dels forholdet mellem de to spor, mellem teori og empiri, hvor især det sidste problem har været diskuteret; men hvor vi dog mener, at det er opfattelsen af den marxske teori, som er hovedproblemet.

Hvis vi mindre ser på de almene programformuleringer, som indeholder en række forbehold overfor en realanalyses gyldighed, og mere ser på det faktiske indhold i den dobbeltsporede fremgangsmåde, kan følgende siges: forholdet mellem teori og empiri blev af Altvater (og af den såkaldte berlinerskole) formuleret som et transformationsproblem mellem værdi og pris. Transformationen mellem værdi og pris blev opfattet som en umiddelbar parallelitet: over et tilstrækkeligt langt tidsrum forudsættes det, at værdiforholdenes og prisforholdenes bevægelser forløber parallelt.

Parallelitetsantagelsen (og for den sags skyld enhver anden antagelse om et fikseret forhold mellem værdi og pris) vil føre til en simpel antagelse af forholdet mellem teori og empiri, som fremtvinger eller forudsætter en speciel opfattelse af teorien og dermed af Marx's Kapitalen. Teorien er der, den skal blot specificeres eller der skal foretages de nødvendige udledninger frem til det niveau, hvor der kan sættes empiri på begreberne. Realanalysen må »... indeholde udledningen af »kapitalbegrebet i almenhed «, altså også fremstillingen af de nødvendigt producerede fremtrædelser helt frem til det borgerlige samfunds overflade $\ll{ }^{23}$ Eller: $\gg$ Det drejer sig [...] om hensyntagen til forholdet mellem almene love, sådan som de kan afledes af kapitalbegrebet $\mathrm{i}$ almenhed, og deres historiske gennemslagsformer og -betingelser i et historisk bestemt samfund. ${ }^{24}$ Citaterne viser den status, som Kapitalen tillægges i undersøgelserne. Herfra opsøges eller udledes de lovmæssigheder, som der dernæst sættes empiri på.

22. Jvf. E. Altvater, m.f.: Kapitalens udviklingsfaser og -tendenser i Vesttyskland; 1. del, Kurasje nr. 12, s. 26-54; 2. del, Kurasje nr. 13, s. 5-96. Jvf. også de kritiske betragtninger i Jens Brinch og Tyge Kjarr: Realanalyserne - to skridt frem og ét tilbage; i: Kurasje nr. 12, s. 8-25. Jvf. endvidere den metodiske udbygning af berlinerskolens position i E. Altvater m.fl: Zum Problem der Profitrateabrechnung - Eine Replik und ein Versuch, das Indikatorenverfahren zu præzisieren; Prokla nr. 24, s. 191-205.

23. E. Altvater, m.fl., op.cit., Kurasje nr. 12, s. 30.

24. E. Altvater, m.fl., op.cit., Kurasje nr. 12, s. 29 (vores fremhævelse). 
Altvater m.fl. har næppe med deres formuleringer om den tosporede fremgangsmåde overskredet arven fra den nedarvede marxisme, og slet ikke i praksis været i stand til det. ${ }^{25}$ Til trods for en understregning af, at de herskende teoretiske og objektive historiske betingelser må medreflekteres og kritiseres, og til trods for bemærkningerne om, at realanalysen også må opfattes som en »væsensanalyse «, ${ }^{26}$ så synes Altvater at mene, at den tosporede fremgangsmådes ene spor: kapitalbegrebets logiske struktur dels bør oparbejdes alment og dels uden videre kan hentes i Kapitalen. Det betyder også, at Kapitalen ikke rekonstrueres, den læses blot med henblik på at uddrage dens logik.

Hermed overses, at Kapitalen i sig selv er et produkt af historiske omstændigheder; det ville være mere konsekvent at tale om, at man i Kapitalen kan hente kapitalbegrebets historisk-logiske struktur, ikke med almen gyldighed, men med gyldighed for den specifikke udviklingsgrad af det kapitalistiske samfund, som Marx betragtede. Vi mener ikke hermed, at rekonstruktionsprogrammet skal gennemføres som en undersøgelse af de oprindelseshistoriske omstændigheder, d.v.s. som en inddragelse af den historiske og teorihistoriske baggrund for Marx's udarbejdelse af Kapitalen (en række omstændigheder, f.eks. Marx's forskellige opbygningsplaner for Kapitalen er nyttige - ingen tvivl om den sag). Rekonstruktionsprogrammet må gennemføres ved en inddragelse af de givne aktuelle historiske omstændigheder. ${ }^{27}$

Sammenfattende: som svar på utilstrækkeligheden i den fra 1930'erne nedarvede marxisme indledte studenterbevægelsen $i$ første del af

25. Berlinerskolens prisindikatorer, men isar deres opfattelse af Kapitalen og den Marxske teori i det hele taget har gennem den senere udvikling hos dem ført til resultater, der tydeligvis falder bag Marx. Fordi forholdet mellem teori og empiri i berlinerskolens formulering er spinkel og yderlig, er forbindelserne til Marx’s uomgængelige videnskabelige resultater forsvundet, og nye begreber er udviklet som erstatning, knyttet til de anvendte prisindikatorer. Det fremgår især af de seneste arbejder, jvf. bl.a. Altvater, Hoffmann, Semmler: Vom Wirtschaftswunder zur Wirtschaftskrise, Berlin 1979; Semmler og Hoffmann: Økonomisk krise, massearbejdsløshed og globalstyring, Kurasje nr. 17, s. 55-92. I Allan Andreassen og Tyge Kjar: Krisen og venstrefløjens handlemuligheder, Kurasje nr. 21, s. 157-186, har vi forsøgt os med en kritik af en kriseforståelse, som er et resultat af den seneste udvikling i berlinerskolen.

26. Jvf. E. Altvater, op.cit., Kurasje nr. 7, s. 24.

27. Med formuleringer lånt fra Engels kan man sige, at rekonstruktionsprogrammet må bestå i en korrektion af Kapitalen, ikke en hvilken som helst korrektion, men en korrektion hvor teoriens fortsatte udvikling ikke vil »... være andet end et spejlbillede af det historiske forløb i abstrakt og konsekvent form; et korrigeret spejlbillede, men korrigeret efter de love, som det virkelige historiske forl $\phi b$ selv frembyder ...« Fra Engels's anmeldelse af Zur Kritik der Politischen Ökonomie, jvf. F. Engels: Karl Marx, »Zur Kritik der politischen Ökonomie«; i: MEW, bd. 13, s. 475 (vores fremhævelse). Med betoningen af det historiske i Kapitalen gør vi os således på ingen måde til fortaler for, at Kapitalen skulle være et historisk forældet dokument. Det det drejer sig om, er forholdet mellem det logiske og det historiske. Det vender vi tilbage til. 
1970'erne en systematisk læsning af Kapitalen med det formål at rekonstruere den.

Kapitalen blev læst udelukkende logisk - som teoriernes bog. Den blev læst med henblik på at uddrage de almene bestemmelser, som dels kunne anvendes til at lokalisere det empiriske og dels kunne danne grundlag for en realanalyse, d.v.s. en analyse af de historiske og specifikke forhold.

I hovedintentionerne og hovedresultatet (lokaliseringen af det empiriske) var der - som det fremgår af den foregående gennemgang - ingen nævneværdige forskelle mellem Altvater og Schanz; det samme gælder for en række andre modsvarende rekonstruktionsfors $\emptyset \mathrm{g}$ fra perioden - selvom der er forskelle i de konkrete fremgangsmåder.

Det empiriske eller det historisk specifikke blev lokaliseret til kapitalen i dens realitet, til profitformen, til prisrelationerne. Kun den del af de aktuelle historiske forhold, som fremtrådte i prisformen, kunne sættes på deres begreb. Denne specifikke opfattelse af Kapitalen førte helt klart til blokeringer af udviklingen af en historisk aktuel marxisme, fordi en oparbejdelse af den marxske teori på denne måde ville gøre den ude af stand til at sammenfatte eller begribe alle relevante historiske forhold, eller tvinge den oparbejdede teori til at bortabstrahere alle de historiske forhold eller sider af historiske forhold, der ikke fremstår i prisform og som der ikke var plads til i en sådan teori. Det er eksempelvis herfra bortabstraheringen af klassemodsætningerne stammer (klassemodsætningerne optræder ganske rigtigt i prisformen: arbejdskraftens pris, men den optræder også adskilt herfra i arbejdersammenslutninger mod borgerskabet).

Det er næppe en tilfældighed, at rekonstruktionen af Kapitalen faldt ud på denne måde. På samme måde, som den nedarvede 1930'er-marxisme spurgte efter det oprindelige, det almengyldige i Marx's lære, så spurgte den rekonstruktive Kapitallæsning klart nok efter det, der havde almen gyldighed i Kapitalen; den spurgte efter det, der måtte antages at have gyldighed uanset kapitalismens udviklingsniveau. I den forstand kan man sige, at rekonstruktionsprogrammet ikke var fyldestgørende; det var ikke i stand til radikalt at bryde med den overleverede marxismes teoretiske praksis, omend den f.eks. var i stand til at bryde med væsentlige dele af denne arvs umiddelbare indhold, f.eks. den reformistiske $\varnothing$ konomiopfattelse.

Trods vores kritik er der derfor ingen grund til at underkende de faktiske resultater fra den systematiske Kapitallæsning, og fra forsøgene på at udvikle en realanalyse. ${ }^{28}$

28. Selvom vi ikke behandler venstrefløjens politiske udvikling må det være på sin plads at nævne, at med udviklingen af en politisk orienteret venstrefløj som afløser for den mere 


\section{Den materialistiske historieopfattelse}

I det foregående har vi forsøgt at give en sammenfattende karakteristik af det udviklingsforløb, som opfattelsen og tilegnelsen af marxismen og især af Kapitalen har budt på i 1960'erne og 1970'erne. Vi har her vist, at de fremherskende udviklingstendenser ikke i udpræget grad har været i stand til at udvikle den marxske teori til en historisk aktuel marxisme. Rekonstruktionsprogrammet, som på den ene side var udtryk for et nødvendigt og det umiddelbart eneste muligt opgør med den nedarvede 1930'er-marxisme, bet $\varnothing \mathrm{d}$ på den anden side en degenerering af marxismen som en materialistisk videnskab ved at blokere for analysen af de virkelige historiske bevægelseslove.

Vores videre argumentation går på, at den materialistiske historieopfattelse må tages alvorligt; det skal vi behandle i dette afsnit. Formålet med at insistere på den materialistiske historieopfattelse skal ikke ses som endnu et fors $\varnothing \mathrm{g}$ på at markedsføre en ganske særlig fortolkningsmulighed med garanteret ægte marxisme. Vi skal ikke konstruere nye systemer; tværtimod - vi er ved at samle forskellige delresultater op fra rekonstruktionsprogrammet og fra realanalyseforsøgene for at påvise en mulig vej ud af de blokeringer, som den logiske kapitallæsning bragte realanalysen i ved at lokalisere det empiriske på en specifik måde.

Det skal vi gøre ved at tage nogle eksempler op på analysefors $\emptyset$ g, som vi kender indefra, og som vi mener tendensielt overskrider disse blokeringer (jvf. afsnit 4). Men først skal vi behandle to problemkomplekser af betydning i denne sammenhæng: filosofien og det logiske og forholdet mellem logik og historie. Vi skal her referere Marx's og Engels's synspunkter med det formål at give en karakteristik af den materialistiske historieopfattelse.

teoretisk orienterede studenterbevægelse fra midten af 1970'erne, blev det, den logiske Kapitallæsning kunne byde på - ikke mindst indenfor den schanzske (eller skulle vi sige den yngre frankfurter skoles) tradition -: »udledningernes uendelighed «, et stadig voksende problem, i klar modsætning til de krav, som den voksende politiske interesse fremkaldte, ikke mindst foranlediget af krisens udvikling. Det udgør uden tvivl den virkelige baggrund for det oprindelige rekonstruktionsprograms mere eller mindre klare sammenbrud. En marxisme, som ikke kunne sikre argitatorisk og politisk skyts til den efterhånden etablerede ikke-reformistiske venstrefløj, fortjente næppe heller dette navn. Det har imidlertid også banet vejen for et tilbagefald til enten den reformistiske eller den borgerlige $\varnothing$ konomiopfattelse. To bøger fortjener - i kraft af deres udbredelse - at blive nævnt som eksempler på dette: Den lange vej gennem krisen, Århus 1976, som falder tilbage på reformismens økonomiopfattelse, og Krisen og den statslige planlagning, Århus 1976, som udelukkende støtter sig på den borgerlige økonomiopfattelse. 


\subsection{Marx og filosofiens og logikkens elendighed}

Vi skal for en kort bemærkning fremholde Marx's opfattelse af filosofi og logik i henholdsvis Den tyske Ideologi og Filosofiens Elendighed, idet disse to skrifter kan opfattes som programmatiske formuleringer af den materialistiske historieopfattelse, som gøres gældende i Marx’s senere »økonomiske « værker.

I kritikken af den selvstændiggjorte filosofi anklager Marx i Den tyske Ideologi filosofferne for at bekæmpe denne verdens fraser med fraser; et sted hedder det: ${ }^{29} » \ldots$ De [ideologierne] har ingen udvikling, men menneskene, som udvikler sin materielle produktion og sit materielle samkvem, udvikler også sin tænkning og sin tænknings produkter med denne virkelighed [...] Der hvor spekulationen ophører, ved det virkelige liv, begynder således den virkelige, positive videnskab, fremstillingen af menneskenes praktiske virksomhed og praktiske udviklingsproces. Fraserne om bevidstheden udgår, virkelig viden må træde i deres sted. Den selvstændige filosofi mister med fremstillingen af virkeligheden sit eksistensmedium. «

Det er en afvisning af nytten i at kritisere filosofien og de ideologiske forestillinger; kritikken af ideologien fører ikke til fremstillingen af de virkelige forhold (fagkritik - nej tak!). Omvendt: fremstillingen af de virkelige, materielle forhold ophæver filosofien og ideologien. Filosofien kan ikke være udgangspunktet (højest et kritiseret slutpunkt); udgangspunktet må derimod være de virkelige materielle forhold: menneskene, deres virkelige, empirisk anskuelige udviklingsproces under bestemte vilkår, som det hedder samme sted. »Forudsætningerne, som vi begynder med, er ikke vilkårlige, det er ikke dogmer, men virkelige forudsætninger som man kun i indbildningen kan abstrahere fra. Det er de virkelige individer, deres handlinger og deres materielle livsvilkår, både dem de fik overleveret og dem de producerede ved sin egen aktivitet. Disse forudsatninger lader sig altså konstatere ad ren empirisk vej.« ${ }^{30}$

Disse programmatiske formuleringer i Den tyske Ideologi er nyttige, ikke mindst sammenholdt med de talrige fors $\varnothing \mathrm{g}$ på at formulere en marxistisk filosofi, som var karakteristisk for 1930'ernes overleverede marxisme-tradition, men også sammenholdt med den tidligere nævnte fremherskende læsetradition af Kapitalen.

I Den tyske Ideologi vil man imidlertid forgæves lede efter en fremstilling af de virkelige, materielle forhold, eller blot konkrete anvisninger på, hvordan en sådan fremstilling må gennemføres. Marx anfører da også udtrykkeligt, at

29. Karl Marx: Die deutschen Ideologie, MEW, bd. 3, s. 27. Udarbejdet i 1845-46.

30. Die deutschen Ideologie, op.cit., s. 20 (vores fremhævelse). 
de vanskeligheder, som fremstillingen af de virkelige forhold giver, ikke skal behandles; i Den tyske Ideologi vil han kun præsentere nogle abstraktioner, som kan bruges overfor ideologien. Det rokker imidlertid ikke ved det forhold, at Den tyske Ideologi indeholder karakteristiske angivelser af programmet for en materialistisk videnskab.

I Filosofiens Elendighed (Proudhon-kritikken) fører Marx kritikken mod filosofferne over på økonomerne. I økonomien fremstilles de borgerlige produktionsforhold, arbejdsdelingen, kreditten, pengene, o.s.v. som faste, uforanderlige, evige kategorier. De forklarer, hvordan der produceres under givne forhold, »... men det de ikke forklarer os, er hvordan disse forhold selv produceres, d.v.s. den historiske bevægelse, der kalder dem til live [...] Men såsnart man ikke forfølger produktionsforholdenes historiske udvikling - og kategorierne er kun det teoretiske udtryk for disse forhold -; såsnart man i disse kategorier kun ser ideer, der er opstået af sig selv, tanker, der er uafhængige af de virkelige forhold, er man med eller mod sin vilje tvunget til at forlægge disse tankers oprindelse til den rene fornufts bevægelser. « ${ }^{31}$

Denne formulering er for såvidt identisk med betragtningerne i Den tyske Ideologi - hvis man ikke forfølger produktionsforholdenes historiske udvikling og ser kategorierne som et teoretisk udtryk for denne udvikling, så ser man ikke disse kategorier som »historiske, forgængelige, forbigående produkter «, ${ }^{32}$ men tillægger kategorierne en egen historie eller eviggyldig status. Heller ikke i Filosofiens Elendighed giver Marx en præcis anvisning på, hvordan den materialistiske historieopfattelse skal udformes, men han giver nogle gode råd til dem, der vil udtænke systemer og leder efter en genfødende videnskab.

I sidste og syvende bemærkning i Filosofiens Elendighed giver Marx nemlig følgende karakteristik af samtidens socialister og kommunister som teoretikere for proletariatet: ${ }^{33}{ }$ Så længe proletariatet ikke er tilstrækkeligt udviklet til at kunne konstituere sig som klasse [...], så længe produktivkræfterne indenfor selve borgerskabets ramme ikke er tilstrækkeligt udviklet til, at de materielle vilkår kan skinne igennem, som er nødvendige for proletariatets frigørelse og oprettelse af et nyt samfund, - er disse teoretikere [socialisterne og kommunisterne] kun utopister som, for at afhjælpe de undertrykte klassers behov, udteenker systemer og leder efter en genfфdende videnskab. Men efterhånden som historien skrider frem og proletariatets kamp făr tydeligere konturer, behøver

31. Karl Marx: Das Elend der Philosophie, MEW, bd. 3, s. 126 (vores fremhævelser). Udgivet i 1847 som en kritik af en bog af Proudhon om elendighedens filosofi.

32. Das Elend der Philosophie, op.cit., s. 130.

33. Das Elend der Philosophie, op.cit., s. 143 (vores fremhævelser). 
de ikke længere at lede efter videnskab i deres hoveder; de skal blot aflagge

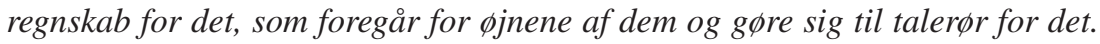
[...] fra dette $\varnothing$ jeblik bliver videnskaben et bevidst produkt af den historiske bevægelse, og den er holdt op med at være doktriner, den er blevet revolutionær.«

Men hvordan skal dette regnskab aflægges; det kan ikke blot være et spørgsmål om at udarbejde en protokol over dagens begivenheder. Det vil føre til det, som Marx i Den tyske Ideologi har karakteriseret som abstrakt empiri, hvormed intet kan begribes.

\subsection{Logik og historie}

I Til Kritikken af den Politiske Ökonomi giver Marx den første positive formulering af den materialistiske historieopfattelse, som sidenhen udvikles i de efterfølgende værker. Bogen er kendt for sit forords formuleringer om, at det materielle livs produktionsmåde betinger den sociale, politiske og åndelige livsproces overhovedet; modsvarende programmatiske formuleringer er allerede fremsat i Den tyske Ideologi. Forordet er ofte blevet opfattet som grundprincipper for den materialistiske historieopfattelse, og har f.eks. været et yndet referancepunkt for den såkaldte historiske materialisme; men forordet er kun at opfatte som program (eller ledetråd). Det er selve bogen, som er et bidrag til udviklingen af den materialistiske historieopfattelse, ikke dens forord.

De problemer, som Marx når en løsning på, har han allerede selv skitseret dels i Den tyske Ieologi og i Filosofiens Elendighed. Problemstillingerne kan sammenfattes således: han må nå frem til en fremstilling af de virkelige materielle forhold, og dermed overskride eller tilintetgøre filosofien og spekulationen. De virkelige materielle forhold må fremstilles begrebsligt, men de kan ikke blot fremstilles udfra i forvejen fikserede kategorier (jvf. Proudhonkritikken); de virkelige materielle forhold må fremstilles udfra den historiske bevægelse, som kalder dem til live.

Det betyder, at produktionsforholdenes historiske udvikling må levere de kategorier, som de virkelige materielle forhold må fremstilles igennem. Men herved opstår de virkelige problemer. Kapitalismens udvikling kan ikke fremstilles udfra de kategorier, som feudalismens historiske udvikling leverer, fordi der her er tale om ensidige, abstrakte (ufuldstændige om man vil) kategorier. Derfor må kapitalismens udvikling fremstilles udfra kategoriernes struktur indenfor det moderne samfund..$^{34}$ Først når det lykkes vil det spekulative og den abstrakte logik være tilintetgjort.

34. Efter at have givet eksempler på udviklingen af forskellige økonomiske kategorier i en række især førkapitalistiske samfundsformer, siger Marx: »Det ville altså være ugørligt og forkert at 
I et brev til Engels siger Marx, at hvis Engels vil anmelde Til kritikken af den politiske фkonomi, så må han ikke glemme, at "proudhonismen er tilintetgjort ved dens rod «. ${ }^{35}$ Det centrale er her forholdet mellem logik og historie; Marx har positivt gjort op med de selvstændiggjorte logiske kategorier, og anvist hvordan de skal forstås som teoretiske udtryk for den kapitalistiske produktionsmådes historiske udvikling.

I sin anmeldelse sammenfatter Engels de resultater, som Marx er nået frem til ved at sammenholde den logiske respektivt den historiske betragtningsmåde. Kritikken af økonomien, siger han, kan gennemføres på to måder: historisk og logisk. Men den logiske behandlingsmåde er »i virkeligheden ikke andet end den historiske kun uden den historiske form og de forstyrrende tilfældigheder. Det historien begynder med, må tankegangen også begynde med, og dens fortsatte udvikling vil ikke være andet end et spejlbillede af det historiske forløb i abstrakt og teoretisk konsekvent form; et korrigeret spejlbillede, men korigeret efter de love, som det virkelige historiske forløb selv frembyder, idet hver moment kan betragtes på det punkt af udviklingen, hvor det har nået sin fulde modenhed, som klassiske form $\ll .36$

Det centrale her er, at kategorierne, begreberne er et teoretisk udtryk for den virkelige histories udvikling. Det får som konsekvens, at det kapitalistiske samfund må have en vis udviklingsgrad, førend dens indre sammenhænge for de forskellige momenter kan begribes. De respektive momenter må have nået sin fulde modenhed, førend begreberne endelig kan fastlægges eller omvendt har fuldt gyldighed. ${ }^{37}$

lade de økonomiske kategorier følge efter hinanden i den rækkefølge, i hvilken de historisk var de bestemmende. Deres rækkefølge er derimod bestemt af den relation, de har til hinanden i det moderne, borgerlige samfund, og som er præcis den omvendte af den, der fremtræder som deres naturlige, eller som modsvarer den historiske udviklings rækkefølge.« Karl Marx: Grundrids, bd. 1, Århus/København 1974, s. 26-27.

35. Marx an Engels, 22. juli 1859, MEW bd. 29, s. 463. Engels må heller ikke glemme, skriver Marx, at han med vareanalysen på ingen måde har analyseret den borgerlige produktions absolutte karakter, kun dens specifikke samfundsmassige karakter.

36. F. Engels: Karl Marx, »Zur Kritik der politischen Ökonomie« (anmeldelse), i: MEW, bd. 13, s. 475. Det har været hævdet, at Engels med formuleringen »Det historien begynder med, må tankegangen også begynde med ...« skulle være i modstrid med Marx (jvf. fodnote 34). Det er imidlertid ikke tilfældet, idet Engels her kun betragter det kapitalistiske samfund, medens Marx i det (i note 34) anførte citat taler om forskellige samfundsformer.

37. Jvf. her Marx's kritik af Ricardo; Ricardo's fejl skyldes ikke tankemæssige fejltagelser, men derimod, at $\phi$ konomiens udviklingsgrad kun tillod ham ensidige abstraktioner; på dette grundlag kunne han derfor ikke formulere værdiloven; Jvf. K. Marx: Theorien über den Mehrwert, MEW, bd. 26.2, s. 161-166. Jvf. også kritikken af fysiokraterne i K. Marx: Zur Kritik der politischen Ökonomie, MEW, bd. 13, s. 42-43. 
Et eksempel: først med udviklingen af den industrielle kapital har værdiproduktionen, kapitalen (eller kapitalforholdet) og akkumulationen nået en sådan modenhed, eller sin klassiske form, at de kan sættes på deres fuldstændige begreb: værdiloven, det almene kapitalbegreb og den almene akkumulationslov (jvf. fremstillingen heraf i Kapitalen). Mellem disse almene begreber er der en indre sammenhæng, svarende til den indre virkelige sammenhæng. Begrebernes sammenhæng kan tankemæssigt fremstilles, men i såfald vil det være en logik af en anden art end den Engels taler om i det tidligere anførte citat. I citatet forstås det logiske som historien sat på begreb; her er det logiske en logisk afledning.

I efterskriftet til Kapitalen præciserer Engels denne sammenhæng i en diskussion af, hvorvidt værdiloven er en fiktion i forhold til den kapitalistiske produktions faktiske forløb; han skriver, at der ikke ${ }^{38} » \ldots$ tages tilstrækkeligt hensyn til, at det her ikke kun drejer sig om en rent logisk proces, men om en historisk proces og dens forklarende genspejling i tanken, om den logiske forfølgelse af den historiske proces's indre sammenhænge.«

De almene begreber - værdiloven, det almene kapitalbegreb og den almene akkumulationslov - fremstiller ikke eller rummer ikke i sig selv den kapitalistiske udviklingshistorie til alle tider. De er momenter, ganske vist af en definitiv og almengyldig karakter; hvis det kapitalistiske samfund har nået et vist udviklingsniveau, så har de fuld gyldighed, svarende til at kapitalen modsvarer sit begreb.

Fra disse almene begreber kan de specifikke udviklingsformer ikke udledes logisk. Var det tilfældet, ville det være muligt at fremstille enhver historie udfra én generel lov. Det, der er muligt - og det Marx gør i Kapitalen (selvfølgelig også i de forudgående værker) -, er en »logisk forfølgelse af den historiske processes indre sammenhænge «, d.v.s. en specifikation af de mulige udviklingsformer, der følger af værdiloven, det almene kapitalbegreb og den almene akkumulationslov.

Først med det historiske udviklingsforløb fastlægges den faktiske af de mulige udviklingsformer, som derfor først kan sættes på dens specifikke historiske begreb, når udviklingen har nået en sådan »modenhed «, at de specifikke årsags-/virkningsforhold for de undersøgte områder fremstår begribeligt.

38. F. Engels: Supplement og efterskrift til III. bog af Kapitalen; i: K. Marx: Kapitalen, Kbh. 1972, 3:4, s. 1148. For tænkningen er der tale om to forskellige processer: begrebsmæssig tilegnelse (forskning) og begrebsmæssig fremstilling, som ikke kan adskilles reelt, jvf. Efterskrift til andet oplag af Kapitalen, hvor Marx skriver: »Ganske vist må fremstillingsmåden i formel henseende adskille sig fra forskningsmåden ...«; K. Marx: Kapitalen, bd. 1:1, Kbh. 1970, s. 195 (vores fremhævelse). 
Forholdet mellem på den ene side den logiske forfølgelse af den historiske processes indre sammenhæng og på den anden side den specifikke konkrete historie skal vi illustrere med to eksempler, vedrørende dels merværdiproduktionsformerne og dels profitratens tendens til fald.

Mervaerdiproduktionsformerne: produktion af den absolutte merværdi udgør det generelle grundlag for det kapitalistiske systems opståen, og samtidig er den absolutte det historiske udgangspunkt for den relative merværdiproduktion. Historisk kommer den absolutte merværdiproduktion således før den relative, men den relative følger ikke historisk efter den absolutte, fordi udviklingen af den relative merværdiproduktion ikke betyder ophør af den absolutte. Så snart den relative merværdiproduktion udvikles, og svarende hertil udviklingen af den specifikke kapitalistiske produktionsmåde (den industrielle kapitals etablering og dermed værdilovens fulde gyldighed), eksisterer de to merværdiproduktionsformer sideløbende.

Er den kapitalistiske produktionsmåde udviklet så vidt, er det imidlertid ikke muligt udfra den nu fuldt gyldige værdilov logisk at fastslå, hvilken form der er fremherskende eller deres indbyrdes rækkefølge. Hvis det ikke var sådan, så kunne f.eks. den historisk fremherskende akkumulationsform afledes logisk af værdiloven.

Hvorvidt den ene eller anden merværdiproduktionsmetode er dominerende, kan konstateres udfra merværdiens bevægelse, d.v.s. udfra udviklingstendensen i merværdiraten eller udbytningsgraden som helhed, og er en følge af en række specifikke historiske betingelser og specifikke årsags-/virkningsforhold, sammenfattet i de historiske specifikke akkumulationsbetingelser og -forløb. Med udgangspunkt heri kan den konkrete historiske udvikling sættes på sit modsvarende, historisk specifikke begreb (f.eks. som en periodiseringsteori for kapitalens bevægelse i Danmark fra 1960 og frem). Dette begreb eller teori vil ikke kunne udledes af de almene begreber, omend det vil være en både logisk og historisk følge af dem. ${ }^{39}$

Profitratens tendens til fald: det samme forhold gør sig gældende for profitratens tendens til fald. Den er blevet opfattet som en absolut lov med almen gyldighed overfor enhver historisk udvikling. Absoluteringen af loven har både været karakteristisk for, hvad der kunne karakteriseres som den objektivistiske

39. Det kan synes selvindlysende, at periodiseringen - kapitalens akkumulationsformer - ikke kan udledes logisk, men må udarbejdes på grundlag af den faktiske historiske bevægelse. Når det er selvindlysende, er det imidlertid et resultat af de allerede gennemførte realanalyser - deres mangler ufortalte. Før de første realanalyser kom frem - hvor især herhjemme må nævnes Jens Brinch: Kapitalakkumulation i Danmark efter 1940; bd. 1 \& 2; Kbh. 1974 \& 1975 - forekom der flere fors $\emptyset \mathrm{g}$ på rent logisk at periodisere kapitalens udviklingshistorie udfra Kapitalens behandling af absolut og relativ merværdiproduktion eller i overgangen fra formel til reel subsumtion. 
kriseteori-tradition (kapitalens automatiske sammenbrud), og for den reformistiske $\varnothing$ konomitradition siden det forrige århundrede. I 1970'erne er loven om profitratens tendens til fald i den absolutistiske form især blevet hævdet af den reformistiske $\varnothing$ konomitradition - ganske vist med modsat fortegn. De har været optaget af at vise, at Marx har begået logiske fejl, ${ }^{40}$ og at den fortløbende akkumulation ikke vil få profitraten til at falde - tværtimod; hvis den falder, skyldes det ikke akkumulation eller overakkumulation, men stigende lønninger (jvf. den såkaldte profitklemmeteori).

Absoluteringen af loven om profitratens tendens til fald hænger sammen med den udelukkende logiske (og brudstyksvise) læsning af Kapitalen.

Først formulerer Marx den generelle lov eller loven som sådan: der vil forekomme et fald i den generelle profitrate. Denne generelle lov er en logisk følge af den almene akkumulationslov. Dernæst formulerer han de hæmmende årsager, hvoraf de væsentligste af dem ligeledes er direkte eller indirekte logiske følger af den almene akkumulationslov. De hæmmende årsager krydser og ophæver virkningerne af den generelle lov, hvorfor der kun er tale om en tendens til et fald i den generelle profitrate. Det er imidlertid ikke en ubestemt tendens.

Fordi loven som sådan såvel som de hæmmende årsager er direkte eller indirekte logiske følger af det samme, af den almene akkumulationslov, sammenfatter Marx slutteligt de to logiske sider af loven om profitratens tendens til fald ved at undersøge udviklingen af lovens indre modsigelser. Marx viser her, at disse modsigelser, som altså kan opfattes som to modsat rettede tendenser af den almene akkumulationslov, med logisk nødvendighed vil føre til krise. Kriserne er disse modsigelsers bevægelsesform.

Men hermed har Marx ikke sagt noget om, hvornår og hvordan kriserne udvikler sig, eller hvad karakter, længde dybde en konkret krise antager. Det vil afhænge af en række specifikke historiske betingelser og specifikke årsags-/virkningsforhold, som ikke kan specificeres logisk, men som fremstår gennem det historiske udviklingsforløb, og må begribes i overensstemmelse hermed.

Sammenfattende: med udgangspunkt i de programmatiske erklæringer i Den tyske Ideologi og Filosofiens Elendighed om den materialistiske historieopfattelse har vi i summarisk form søgt at vise, hvordan Marx indløste programmet: fremstillingen af de virkelige materielle forhold udfra den historiske be-

40. Selvom det ikke er sagen vedkommende i denne sammenhæng, bør det dog nævnes, at Marx's såkaldte logiske fejl er værdiloven, som den reformistiske $\emptyset$ konomitradition af politiske grunde i mere end 80 år har søgt at modbevise teoretisk og logisk. 
vægelse, som kalder dem til live, og hvordan den historiske udvikling leverer de kategorier, som de virkelige materielle forhold må fremstilles igennem. Det afgørende er her forholdet mellem logik og historie, nærmere betegnet forholdet mellem den historiske bevægelse, det logiske som historien sat på begreb, og det logiske som fremstillingen af den historiske processes indre sammenhæng.

Sammenhængen mellem logik og historie er derfor ikke et spekulativt spørgsmål, men et spørgsmål, hvis besvarelse må opsøges i den historiske proces. Eller udtrykt i andre, men modsvarende begreber: forholdet mellem det almene og det specifikke i dets konkrete historie er ikke et spørgsmål, hvis svar man skal »lede efter i hovedet«; svaret må søges i den historiske bevægelse. Forholdet logik - historie kan ikke sættes på en logisk formel.

Vi kan her igen ty til Engels. I forordet til Kapitalens tredie bind siger han, at det er en misforståelse, ${ }^{41} \gg \ldots$ at man i det hele taget hos Marx kan lede efter fiks og færdige og for al evighed gyldige definitioner. Det er selvindlysende, at dér hvor man ikke opfatter tingene og deres indbyrdes relationer som uforanderlige, men netop foranderlige, må også tingenes afbildning i tanken, begreberne, ligeledes vare udsat for forandring og omdannelse; at man ikke indkapsler dem i stive definitioner, men udvikler dem i den proces, hvorved de historisk, respektive logisk bliver til.«

Som det tidligere er påvist, skete fastlæggelsen af det empiriske både hos Schanz og Altvater ved, hvad der kunne karakteriseres som, at sætte historien på logisk formel. ${ }^{42}$

Det befordrer det standpunkt, at logikken kan hentes i Kapitalen og historien kan tilføjes de almene værdiformsbestemmelser eller det almene kapitalbegreb, for såvidt den undersøgte historie omhandler kapitalen i dens realitet, profitformen eller prisrelationerne.

Man kan sige, at den måde som det empiriske problem blev lokaliseret på, nødvendigvis måtte føre til en skarp adskillelse mellem det logiske og det historiske, og til en vidtgående indskrænkning af, hvad der overhovedet skal forstås ved historien eller ved det empiriske. I den realanalyse, som følger af en sådan opfattelse, er det logiske givet på forhånd; det empiriske problem forudsættes at bestå i en umiddelbar påvisning af, hvordan de almene bestemmelser specifikt udfolder sig på samfundets overflade. En sådan realanalyse kan i heldigste fald ende med at vise, at kapitalisme er kapitalisme, at værdiloven gælder også for

41. F. Engels: Forord (til Kapitalens tredie bind); i Kapitalen, Kbh. 1972, bd. 3:1, s. 21 (vores fremhævelser).

42. Jvf. en modsvarende kritik heraf hos Thomas Andersen, Jens Herskind og Hjalte Tin Iversen: Kapitalismens alder og vitalitet; i Kurasje nr. 19/20, s. 135-194 (især s. 135-147). 
denne fabrik, og at den slår igennem på samfundets overflade. I såfald vil den kun i begrænset omfang kunne bidrage til at sætte den historiske bevægelse på dens rette begreb.

\section{Realanalysen som materialistisk historieopfattelse}

Det problem, som uden tvivl har virket mest blokerende på udviklingen af en historisk aktuel marxisme, er forholdet mellem vardi og pris og de løsninger, som har været fremsat på dette problem. Værdi-prisforholdet er blevet formuleret som et logisk problem, hvis løsning kunne sikres gennem den rette antagelse eller de rette definitioner; hermed er værdiprisforholdet næppe blevet forstået, og i hvert fald ikke blevet forstået som et historisk, virkeligt forhold mellem den kapitalistiske produktionsproces, cirkulationsprocessen og de hertil hørende distributionskategorier.

Vi har tidligere været inde på værdi-pris-problemet eller det såkaldte transformationsproblem i forbindelse med behandlingen af berlinerskolens rekonstruktionsprogram. Vi nævnte her, at antagelsen af en parallelitet mellem værdi og pris såvel som ethvert andet fikseret forhold mellem værdi og pris vil føre til en forsimpling af forholdet mellem teori og empiri - mellem logik og historie.

Vi skal vende tilbage til problemstillingen ved at stille spørgsmålet: hvorfor er parallelitetsbetragtningen ikke gyldig og hvorfor er det såkaldte transformationsproblem en fiktion?

\subsection{Værdi og pris}

Grundproblemstillingen kan karakteriseres således: arbejdstid eller slet og ret arbejde materialiseres gennem den umiddelbare produktionsproces i vareprodukter som værdi. Gennem cirkulationen forvandles værdien til pris. Formforvandlingen, som består $\mathrm{i}$, at værdi bundet til vareproduktet forvandles til pris udtrykt symbolsk f.eks. i pengesedler, er selvindlysende og rejser ikke problemer i denne sammenhæng. Problemet angår alene det storrelsesmassige forhold mellem vardi og pris. Problemstillingen er derfor: hvorfor falder værdi og pris størrelsesmæssigt fra hinanden. 
Den enkeltkapital, der anvender overgennemsnitlig arbejdstid pr. produkt, realiserer ikke hele den tilsatte værdi respektiv arbejdstid, men kun en del. Her er værdi og pris ikke sammenfaldende. På samme måde med den enkeltkapital, som anvender undergennemsnitlig arbejdstid pr. produkt; her realiseres en pris, som mere end modsvarer den til vareproduktet tilsatte værdi respektiv arbejdstid.

Med andre ord og for det første: gennem konkurrencen indenfor branchen, hvorigennem der dannes ens markedsværdier, fremkommer der en afvigelse mellem værdi og pris i samme udtrækning, som branchens enkeltkapitaler anvender varierende arbejdstid til fremstilling af det samme produkt.

Men ikke nok med det. Også konkurrencen mellem brancherne får indflydelse på forholdet mellem værdi og pris. I en branche, hvor en kostprissænkning eksempelvis frembragt gennem forvandling af alle produktionsprocesserne i branchen, har medført en overgennemsnitlig profitrate, vil der strømme kapital til. Med den tilstrømmende kapital udvides produktionens omfang, konkurrencen skærpes; gennem heraf resulterende prisfald sker der et fald i den værdistørrelse, som den samlede branche realiserer, og der sker en udligning af branchens profitrate til et almindeligt niveau.

Med andre ord og for det andet: gennem den proces, hvor tendensen til dannelse af en almen profitrate, d.v.s. dannelse af produktionspriser, sættes igennem, falder værdi og pris størrelsesmæssigt yderligere fra hinanden. Der sker en yderligere udvendigg $\phi r e l s e$ af forholdet mellem værdi og pris. ${ }^{43}$

Det er således konkurrencen i dens to former: dannelsen af markedsværdien og dannelsen af produktionspriser (kostpris + gennemsnitsprofit), som medf $\varnothing$ rer, at værdi og pris størrelsesmæssigt aldrig vil være sammenfaldende. (Skulle de momentvis være sammenfaldende, beror det på en tilfældighed). ${ }^{44}$

Men hermed er ikke alt sagt. I forhold til konkurrencens to former har verdensmarkedet en særlig stilling. På verdensmarkedet, d.v.s. ved handel udover den nationale kapitals rammer gør de to former for konkurrence sig også gæl-

43. Marx's fremstilling heraf i tredie Kapitalbinds første 10 kapitler; jvf. specifikt Kapitalen, bd. 3:1, Kbh. 1972, s. 62.

44. Derfor kan man ikke løse det såkaldte transformationsproblem ved at tage udgangspunkt i sådanne momenter, f.eks. ved at tage udgangspunkt i en gennemsnitlig branche eller konstruere en gennemsnitsbranche som målestok. Det fører til en statisk opfattelse af forholdet mellem produktionsforhold og distributionsforhold eller fører til, at alle bevægelser synes at udspringe af distributionsforholdene eller cirkulationen (jvf. Matticks kritik af transformationsproblemet - se fodnote 49). Sådanne fors øg er på forhånd dømt til at mislykkes. Som eksempel på sådanne forsøg jvf. Ole Fogh Kirkeby: Marxismen som $\emptyset$ konomisk videnskab, Roskilde 1979, som da også ender med et subjektivistisk arbejdsværdilærestandpunkt. 
dende. ${ }^{45}$ Gennem udviklingen af verdensmarkedet fremstår der imidlertid også en konkurrence nationerne imellem, d.v.s. imellem de nationale totalkapitaler, som får et sammenfattet udtryk i de forskellige nationale valutaer, disse valutaers indbyrdes relationer, og forskydninger i disse valutarelationer. De nationale valutaers styrke og udviklingen heri kan føres tilbage til det pågældende lands samlede produktivkraftudviklingsniveau og forskydninger i dette udviklingsniveau. Valutaerne og deres indbyrdes forskydninger betyder, at værdi og pris yderligere størrelsesmæssigt falder fra hinanden; eksempelvis vil et land med en svag valuta ved verdenshandel realisere en formindsket pris i forhold til den nationalt tilsatte værdi.

Med andre ord og for det tredie: udviklingen af en sporadisk udenrigshandel til et egentligt verdensmarked fører til, at det størrelsesmæssige forhold mellem værdi og pris yderligere falder fra hinanden, altså yderligere udvendiggøres.

Denne oversigt over udviklingen af størrelsesforholdet mellem værdi og pris må ikke opfattes som definitioner. ${ }^{46}$ Vi har ikke andet end fremstillet den historiske proces, hvorigennem den kapitalistiske cirkulationsproces og dens distributionskategorier udvikles, og hvorigennem forholdet mellem værdi og pris udvendiggøres i en sådan grad, at priserne og profitten i det udviklede kapitalistiske samfund fremtræder uden oprindelse i værdi og merværdi.

Den historiske proces, hvorigennem distributionsforholdene udvikles, følger meget nøje den kapitalistiske produktionsprocesses udvikling. Markedsværdier findes etableret forud for kapitalistisk produktion i den såkaldte simple vareproduktion (hvor markedsværdierne selvfølgelig ikke er knyttet til værdiproduktionen, og kun omfatter begrænsede produkter i forhold til dette samfunds materielle fornødenheder); produktionspriserne udvikles gennem etableringen af den industrielle kapital, d.v.s. den specifikke kapitalistiske produktionsmåde og med den kapitalens bevægelige former (aktiekapital og andre former for det, der kaldes ansvarlig kapital). Udviklingen af verdensmarkedet til et sådant omfang, at det griber ind i de nationale kapitalers »livsatmosfære«, følger af kapitalismens ekspansion på verdensplan.

Vi skal vende tilbage til spørgsmålet om det såkaldte transformationsproblem og parallelitetsbetragtningen. Udfra det vi har sagt i det foregående, er det klart,

45. Dannelsen af produktionspriser på verdensplan sker dog for den givne historiske udvikling kun i modificeret form, idet den fulde udfoldelse af den til verdensproduktionspriserne hørende konkurrence forudsætter eksistensen af en - i det mindste tendensiel - verdenskapital.

46. Jvf. det tidligere anførte Engels-citat, angivet i fodnote 38. 
at en forudsætning om parallelitet mellem værdi og pris er det samme som at abstrahere fra konkurrencen, idet forudsætningen kun er almen gyldig, hvis de former for konkurrence, som vi har beskrevet i det foregående, ikke findes.

Men ikke nok med det; parallelitetsbetragtningen er også en abstraktion fra den historiske proces, hvorigennem de kapitalistiske distributionsforhold udvikles, og hvorigennem forholdet mellem værdi og pris udvendiggøres. Heraf følger, at det er en teoretisk umulig generel forudsætning eller abstraktion at gøre, hvis det drejer sig om at studere fremtrædelserne på samfundets overflade, hvor konkurrencen er forudsat, og hvor de historisk specifikke distributionsforhold gør sig gældende. ${ }^{47}$

Nu kunne man hævde, at det såkaldte transformationsproblem og parallelitetsbetragtningen som et svar på problemet skal opfattes som et forsøg på en generalisering over forløbet af alle de handelstransaktioner, som f.eks. over et år formidler værdiens forvandling til pris gennem talrige $k ø b$ og salg. Det er imidlertid en empirisk umulig generalisering og det er umuligt at generalisere på anden vis om handelstransaktionernes forløb, fordi summen af værdierne f.eks. over et år udspaltes og opdeles gennem konkurrencen og dens virkninger på en sådan måde, at det er umuligt at genkende det specifikke værdiindhold i f.eks. årets varepriser. ${ }^{48}$

Transformationsproblemet og parallelitetsbetragtningen som en »løsning « herpå er snævert forbundet med eller fremtvinger den type af realanalyse, hvor det drejer sig om empirisk at fremstille de almene bestemmelsers fremtrædelse

47. Det er bemærkelsesværdig, at Altvater m.fl. i den artikel, hvor de går udfra parallelitetsbetragtningen, samtidig i den teoretiske del af artiklen gennem henvisninger til J. Cibulka taler om »mangfoldigheden af kategoriernes kausalforbindelse på det borgerlige samfunds overflade ...« uden at gøre sig klart, at der her er tale om fænomener, som Marx i Kapitalbind III har begrebsliggjort gennem behandlingen af konkurrencen, dens former, dens udfoldelse gennem profitproduktionsmetoderne og dens virkninger på arbejdslønnen, m.v. - som samlet omhandler distributionsforholdenes historiske udvikling, deres betingethed af og deres indvirkning på produktionsforholdene. Man står altså ikke på bar bund overfor alle disse kausalforbindelser på det borgerlige samfunds overflade. (Altvater, m.fl: Kapitalens udviklingsfaser og -tendenser i Vesttyskland, 1. del, Kurasje nr. 12, s. 36).

48. I Kapitalen siger Marx: »hvis man betragter totalkapitalen i samfundet, er værdisummen af de varer, den producerer (eller udtrykt i penge, deres pris) = værdien af den konstante kapital + værdien af den variable kapital + merværdi«; jvf. Kapitalen, bd. 3:1, Kbh. 1972, s. 216. Denne formulerings gyldighed forudsætter, at der ses bort fra verdensmarkedet (verdensmarkedet er endnu ikke inddraget i behandlingen på dette sted - efter planen skulle det komme senere, men som bekendt nåede Marx det ikke). Formuleringen er blevet anvendt som en løsning på det såkaldte transformationsproblem: et års priser udtrykker årets værdiproduktion; men det er selvklart ingen $1 \varnothing$ sning, idet den som enhver anden løsning på det sk. transformationsproblem bortabstraherer distributionsforholdene på ukontrolleret vis; herudover er den empirisk ufremkommelig. 
på den samfundsmæssige overflade, d.v.s. hvor det drejer sig om en logisk fikseret teoris empiriske genspejling. Vi har tidligere argumenteret mod den type af realanalyse og mod at opfatte realanalyse på denne måde; vi skal derfor ikke gentage kritikken her.

Lad os sammenfatte foreløbigt på følgende måde: parallelitetsforudsætningen er en dårlig, ugennemtænkt og utilsigtet abstraktion, fordi det er en abstraktion som ukontrolleret ophæver det, der er til undersøgelse. Den måde at opstille det empiriske problem på - som et transformationsproblem - er en fiktion, fordi det ikke modsvarer virkelige forhold. Transformationen mellem værdi og pris eksisterer ikke som andet end hvert enkelt varebyttes problem. ${ }^{49}$

Parallelitetsbetragtningen eller andre måder alment at fiksere værdiprisforholdet på er imidlertid også en hel unødvendig forudsætning at gøre for at kunne forholde sig til de fremtrædende forhold på det borgerlige samfunds overflade, d.v.s. kunne anvende statistisk materiale ved analysen af konkrete forhold. (Med statistisk materiale tænker vi denne sammenhæng udelukkende på kvantitative oplysninger i prisform; det er selvklart ikke den eneste form for materiale, som kan eller bør anvendes).

Løsningen på det empiriske problem består således ikke $\mathrm{i}$ at håndhæve et generaliseret forhold mellem værdi og pris - ikke mindst fordi det fører til en omdefinering af det empiriske problem og fører til vilkårlige abstraktioner.

Udveje fra de transformationslogiske blokeringer er snublende nær. I stedet for at anvende generelle forudsætninger for forholdet værdi-pris, som fører til vilkårlige og ukontrollerede abstraktioner, anvendes abstraktioner, som er gyldige i forhold til den undersøgte konkrete historie. Det skal vi

49. Jvf. Matticks afvisning af transformationsproblemet i artiklen »Samuelsons »transformation « af marxismen til borgerlig $\varnothing$ konomisk teori«, i: Paul Mattick: Kritik af neomarxisterne; Kbh. 1974, s. 256-269. Matticks kritik af Samuelson er en gyldig og eksemplarisk kritik af enhver generaliseret betragtning mellem værdi og pris. I den del af artiklen, hvor han fremstiller Marx's opfattelse af sagen, ender han imidlertid i et standpunkt, som umuligg ør eller implicit afviser det, som Marx karakteriserer som en undersøgelse af »... hvorledes den kapitalistiske produktions immanente love fremtræder i kapitalernes ydre bevagelse, hvorledes de [de immanente love] gør sig gældende som konkurrencens tvangslove og derfor opstår i den individuelle kapitalists bevidsthed som herskende motiver ...« (Kapitalen, Kbh. 1970, bd. 1:2, s. 475). Mattick underkender ganske simpelt det nødvendige indre forhold mellem produktionsforhold og distributionsforhold. Jvf. desangående også »Metodiske/teoretiske problemer omkring empiriske analyser af profitratefaldet. Den nuværende krise og den politiske strategi. Diskussion mellem Elmar Altvater og Paul Mattick«, Kurasje nr. 12, s. 55-80. 
belyse nærmere.

\subsection{Realanalyse som begrebsliggørelse af den konkrete historie. To ek- sempler}

Gennem artiklen har vi argumenteret for, at udviklingen af en historisk aktuel marxisme forudsætter en genskabelse af den materialistiske historieopfattelse, d.v.s. en begrebsliggørelse af den umiddelbart foreliggende virkelighed med begreber, som den materielle virkelighed selv gennem den historiske proces danner grundlag for. Begrebsliggørelse af historien på dens eget grundlag - kunne man sige. Anvendelsen af abstraktionsproceduren er den eneste mulige vej, d.v.s. at se bort fra ubetydende momenter i historien, studere det simple før det komplekse, o.s.v. Der er ingen genveje eller bagveje..$^{50}$

Vi mener ikke ukontrollerede eller vilkårlige abstraktioner, men abstraktioner, der modsvarer og ikke skygger for de historiske aspekter af den konkrete historie, som er til unders $\emptyset$ gelse. Vi siger tydeligvis aspekter, fordi vi mener, at det ikke er muligt at fors $\varnothing$ ge sig med en konkret »total«historie - det er i hvert fald uden tvivl nyttesløst i betragtning af den tid, det vil tage, og de kræfter der skal bruges. Det må imidlertid understreges, at ikke hvilke aspekter som helst af den umiddelbare historiske virkelighed kan unders $\varnothing$ ges eller i det mindste danne udgangspunkt for undersøgelse ad denne vej. Det ligger allerede klart udfra det, der tidligere er sagt om den materialistiske historieopfattelse; udgangspunktet må være de materielle forhold $\mathrm{i}$ almindelighed - og den umiddelbare produktionsproces $\mathrm{i}$ særdeleshed.

Vi sagde før vedrørende anvendelsen af abstraktionsproceduren, at man med den skulle se bort fra de ubetydende momenter. Hvad er ubetydende og omvendt hvad er betydende momenter; hvor kan vi vide det fra?

Vi kan give tre svar, hvor ikke blot ét af dem er et tilstraekeligt kriterium,

50. Der er ellers forslag nok til genveje og bagveje, såsom: genoplive filosofien; slå sig til tåls med uangribelige almindeligheder om den konkrete historiske udvikling; beskæftige sig med noget andet og mere vigtigt for så at opgive udgangspunktet i de materielle forhold og deres udvikling - kort sagt: søge tilbage til de degenerede marxistiske traditioner. Selvom vi på en del punkter ikke kan være uenige med Chr. Toft i hans kritik af berlinerskolen (jvf. Chr. Toft: Kritik af realanalysen, Kurasje nr. 25, s. 9-48), så er det nonsens, hvis man udstrækker denne kritik til enhver realanalyse og alternativet - fagkritik som metode (jvf. fodnote 10) - er at opgive ethvert fors $\varnothing \mathrm{g}$ på at arbejde udfra den materialistiske historieopfattelse. Med en omskrivning af Marx's Proudhon-kritik kunne man stille spørgsmålet: hvad kan den type af fagkritik byde på andet end fagkritikerens egen moral? 
og hvor ingen af dem går forud, men derimod er en del af undersøgelsen. 1) Vi kan vejledes af Marx's videnskabelige resultater: de almene love og de mulige udviklingsformer eller gennemslag, herunder en skærpelse af begreberne i forhold til den unders $\emptyset$ gte historie. 2) Vi må undersøge, om det gennem de foretagne abstraktioner er muligt at opspore de indre sammenhænge i den konkrete historie, d.v.s. er det lykkedes at udforske den konkrete histories begreb. 3) I forbindelse hermed må det undersøges, om det er muligt på basis af det udforskede begreb at sammenfatte eller fremstille alle de forhold, som der blev set bort fra i første omgang, og som knytter an til den unders $\varnothing$ gte konkrete historie.

Det er altsammen betydeligt lettere sagt end gjort. Fordi det drejer sig om at foretage abstraktioner, som må afspejle den umiddelbart foreliggende materielle virkelighed, er det ikke muligt at fremsætte almene betragtninger om sagen - udover det vi allerede er kommet med, og hvis almene gyldighed der nok må sættes et spørgsmålstegn ved. Vi kan ikke angive almene formler for de nødvendige abstraktioner.

Vi skal derfor forsøge at belyse det med to eksempler: dels ét vedrørende den statslige krisepolitik og dels ét vedrørende den umiddelbare produktionsproces. ${ }^{51}$

Forste eksempel: artiklen »Arbejderklassens situation og den statslige krisepolitik « er et fors $\varnothing \mathrm{g}$ på at fastlægge den statslige krisepolitiks historisk specifikke begreb. Vi skal først give et referat af artiklens hovedproblemstillinger, og dernæst se på, hvordan forholdet mellem værdi og pris er behandlet.

Hovedproblemet kan siges at bestå $\mathrm{i}$ at vise, hvordan statsapparatet konkret er knyttet til kapitalforholdet og dermed til udbytningsforholdene og deres udvikling i den undersøgte periode - fra krisegennemslaget i 1974/75 og frem. Problemet består altså i at undersøge den historisk specifikke sammenhæng mellem stat og kapital, mellem statspolitik og kapitalakkumulation, hvor statspolitikken ikke kan forstås som et historisk resultat af sig selv (kan f.eks. ikke forstås som keynesiansk statspolitik ${ }^{52}$ ), og kan langt fra

51. Nemlig artiklerne Allan Andreassen og Tyge Kjar: Arbejderklassens situation og den statslige krisepolitik; Kurasje nr. 25, s. 81-126; og Tyge Kjar: Udviklingen på Helsingør Værft. Udviklingen fra 1950'erne til i dag, belyst udfra analyser af regnskaber, teknologiudvikling

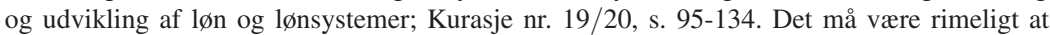
understrege, at vi ikke opfatter dem som fuldfærdige unders $\emptyset$ gelser, men eksplicitte fors $\emptyset \mathrm{g}$ på at løse blokeringerne. 
begribes udfra almene betragtninger om forholdet mellem kapitalakkumulation og stat, men må forstås som et »sammenfattende resultat af de materielle betingelser for kapital, stat og arbejderklasses ageren under de givne historiske omstændigheder. ${ }^{53}$

Kapitalforholdet og hermed klasseforholdet fremtræder ikke umiddelbart, men fremstår som distributionsforhold. Derfor tages der undersøgelsesmæssig udgangspunkt i de relevante dele af de kapitalistiske distributionsforhold og deres tilhørende overfladefikserede kategorier: $1 \varnothing$ n, profit og skat. Under spørgsmålet, hvor stammer skatten fra, føres disse distributionskategorier teoretisk tilbage til deres modsvarende værdibegreber: profit og skat som merværdi, og (disponibel) løn som arbejdskraftens værdi. Med andre ord distributionskategorierne føres tilbage til værdiloven og det almene kapitalbegreb, og hermed tilbage til klasseforholdet. Udfra empirisk materiale illustreres de konkrete former, hvorigennem den del af merværdien, staten beslaglægger, distribueres til statsapparatet. Gennem illustrationerne bliver det påpeget, at distributionsformerne ikke kun er spejlbillede af produktionsforholdene, men at der gennem skattens distribution til statsapparatet momentvis kan opstå tillægsudbytning (som i artiklen betegnes som sekundær udbytning).

Det ovenstående kan forsåvidt opfattes som almene bestemmelser, hvor begreberne er skærpet eller praciseret i forhold til den unders $\phi$ gte historie. Da statsapparatet ikke er merværdiproducerende, men merværdiforbrugende, fører disse bestemmelser til, at der nødvendigvis må findes en indbyrdes front mellem stat og kapital, når det drejer sig om merværdiens deling; men en fælles front rettet mod den produktive totalarbejder, når det drejer sig om den absolutte størrelse af merværdien. På denne måde fremgår den borgerlige stats klassekarakter; den er indmejslet $i$ de historisk givne produktions- og distributionsforhold, og sammenhaengen herimellem.

Der findes imidlertid også nogle historisk mere specifikke momenter, som må inddrages, nemlig følgende: hovedparten af merværdien henholdsvis profitten, som tilfalder statsapparatet, distribueres via lønformen. Reproduktion af overskudsbefolkningen er gennem den historiske udvikling her i landet blevet et statsanliggende, som betyder, at denne del af befolkningen reproduceres udenfor lønarbejde-kapitalforholdet, og derfor er underlagt de reproduktionsvilkår, som statsapparatet fastlægger. Og endelig statsapparatets dominerende størrelse, både hvad angår den mængde arbejdskraft, den

52. Det ville netop betyde, at statspolitikken blev forstået som resultat af »ideer«, og ikke som resultat af den materielle virkelighed.

53. Arbejderklassens situation og den statslige krisepolitik, op.cit., s. 111. 
opsuger, men især hvad angår størrelsen af den profitmasse, som staten beslaglægger. Det er naturligvis ikke resultat af tilfældige, men produkt af en række historiske nødvendigheder.

På basis af de almene og de historisk specifikke momenter opstilles en oversigt over mulige logiske former for en krisepolitik, som udfra de $h i$ storiske forhold enten kan føre til et ændret delingsforhold af profitmassen mellem stat og kapital, eller til en forøgelse af den profitmasse, som er til deling.

Dernæst undersøges, hvordan de logiske muligheder for krisepolitikken konkret udfoldes. Resultaterne, som må opfattes som et forsøg på at fastlægge den statslige krisepolitiks historisk specifikke begreb, skal vi ikke gengive her; men blot understrege, at den refererede unders $\varnothing$ gelse kun fors $\emptyset$ ger at opspore de indre sammenhænge i krisepolitikken, hvormed menes krisepolitikkens indre sammenhæng med produktionen. Der abstraheres fra en række omstændigheder, som påny må inddrages eller fremstilles, hvis en sammenhaengende begribelse af den aktuelle krisepolitik skal blive resultatet. ${ }^{54}$

Både det statistiske materiale, som anvendes illustrativt til præcisering af begreberne (artiklens afsnit 2), og det materiale, som anvendes til at undersøge den konkrete krisepolitiks udvikling (i afsnit 3), rejser nogle principielle problemer, som skal diskuteres.

Det er indlysende, at undersøgelsen ikke kan gennemføres, hvis det ikke er muligt at forbinde værdiproduktionen med de fremtrædende distributionskategorier. Statspolitikkens virkninger på udbytningsforholdene gennem beskatning og anvendelse af de statslige udgifter (art og omfang) forudsætter, at det er muligt empirisk at belyse udviklingen af produktionsforholdene og distributionsforholdene og sammenhængen herimellem. Artiklen løser dette empiriske problem gennem to abstraktioner og én generalisering.

I artiklen sættes totalmerværdimassen lig med totalprofitmassen, hvad deres størrelse angår. ${ }^{55}$ Det er en abstraktion; spørgsmålet er, hvad der abstraheres fra. Udfra hvad vi tidligere har sagt (jvf. afsnit 4.1), så abstraheres der fra den udvendiggørelse af forholdet mellem værdi og pris, mellem merværdi

54. Det kan diskuteres, om realanalysen skal udvikle en sådan »sammenhængende begribelse«, og om den ikke snarere kunne, ville, eller burde fremstå som resultater af politisk praksis, som derfor knytter an til og kritiserer de opsporinger af indre sammenhænge, som realanalysen i såfald skulle koncentreres om.

55. Der er således ikke tale om, at forudsætte en identitet, idet værdi og pris som tidligere nævnt har forskellig naturalieform; derimod er der lighed, hvad deres størrelse angår. Marx går udfra det samme i tredie bind af Kapitalen, fordi verdensmarkedet endnu ikke er inddraget her, jvf. eksempelvis Kapitalen, Kbh. 1972, bd. 3:2, kap. 15; derimod falder merværdi og profit, merværdirate og profitrate fra hinanden, som følge af konkurrencen. 
og profit, som følger af verdensmarkedet, og den konkurrence den fremtvinger de nationale stater imellem. Sattes totalmervardimassen størrelsesmassigt lig med totalprofitmassen abstraheres der således fra verdensmarkedet. Omend verdensmarkedet spiller en rolle for udviklingen af krisen, så spiller den næppe nogen direkte rolle for, hvordan statsapparatet gennem de relevante dele af distributionsforholdene søger at påvirke produktionsforholdene, eller mere specifikt udbytningsforholdene. Det er således en gyldig abstraktion i forhold til den unders $\varnothing$ gte konkrete historie, og det er en abstraktion, som det ikke er nødvendigt at ophæve igen igennem videre undersøgelser.

Næste problem er, at det ikke er muligt at identificere totalprofitmassen empirisk, fordi det ikke er muligt udfra statistikken at skaffe de nødvendige oplysninger om den samlede profitproduktion i hele den umiddelbare produktionsproces. Som løsning herpå foretages der en generalisering udfra den industrielle arbejder, idet den industrielle arbejders udbytningsforhold og profitproduktion tages som et empirisk gyldigt udtryk for den produktive totalarbejders udbytningsforhold og profitproduktion, fordi »forholdene skal være meget afvigende indenfor de $\emptyset$ vrige produktionsområder [landbrug, fiskeri, håndværk], hvis denne forudsætning ikke holder, fordi den industrielle produktion er langt den dominerende del af den kapitalistiske produktion $\ll .{ }^{56}$ Generaliseringen gennemføres som en gennemsnitsbetragtning; det, der empirisk opereres med, er således totalmerværdimassen henholdsvis totalprofitmassen i gennemsnit for den produktive totalarbejder.

Tilbage står imidlertid nok det mest afgørende problem. Den profitmasse, som umiddelbart kan identificeres, er ikke hele den producerede profitmasse; efter de beregningsmetoder, der anvendes, er profitmassen ganske vist ikke spalte op i industrielle driftsprofitter, rente og skat af kapitalrevenuer ${ }^{57}$ men den del, der distribueres til staten via lønformen, og den del, der tilfalder handelskapitalen, er spaltet ud; den første gennem den variable kapital, som består af disponibel løn og skat; den anden gennem engros-markedspriser. Udfra gennemsnitlige beskatningsprocenter kan den del af profitmassen, som distribueres til statsapparatet, imidlertid let føres tilbage. Det samme gælder ikke for handelskapitalens profitter; det er her nødvendigt at se bort fra den. Denne abstrahering - som er den anden af de omtalte abstrak-

56. Arbejderklassens situation og den statslige krisepolitik, op.cit., s. 113.

57. Det vil føre for langt her at komme ind på de eksakte beregningsmetoder, men så meget kan dog siges: fra produktionsværdien (årets salg, korrigeret for lagerforskydninger) fratrækkes $1 \varnothing n n i n g e r$ og materialeudgifter; endvidere fratrækkes $1 / 10$ af den fixe konstante kapital. Den resterende størrelse er så profitmassen. (Jvf. dog efterfølgende i teksten). 
tioner - giver en fejl, som dog ingen praktisk betydning har, med mindre handelskapitalen pludseligt formindsker eller forøger sin andel af totalprofitmassen. Da det imidlertid er en abstraktion under kontrol - på linie med abstraheringen fra verdensmarkedet - betyder det, at disse abstraktioner påny kan inddrages $\mathrm{i}$ betragtningen gennem den videre undersøgelse, hvis det udfra unders $\varnothing$ gelsesgenstanden viser sig nødvendigt, hvis f.eks. handelsprofitternes bevægelse viser sig som afgørende for den statslige krisepolitiks udstilling.

Gennem de omtalte abstraktioner og under forudsætning af den anførte generaliserings gyldighed er det således muligt at beregne udbytningsgrad, den statslige krisepolitiks virkninger på udbytningsgraden, o.s.v. Transformationslogikkens fiktive problemer og parallelitetsbetragtningens blokeringer forsvinder således med en bevidst anvendelse af abstraktioner, som er gyldige i forhold til unders $\varnothing$ gelsesfeltet.

Andet eksempel: med artiklen »Udviklingen på Helsingør Værft« kan vises, hvorfor de nødvendige abstraktioner i relation til værdi-pris-forholdet må modsvare undersøgelsesgenstanden for ikke at skygge for det, der er til unders $\emptyset$ gelse. Vi skal som ved det foregående eksempel imidlertid ikke gå i detaljer, men henvise til artiklen. ${ }^{58}$

Udgangspunktet for undersøgelsen var værftsledelsens trusler om lukning, som i deres argumentation blev kædet sammen med faldende beskæftigelse, faldende overskud, som angiveligt altsammen skulle hænge sammen med for høje lønninger og for lav produktivitet.

Formålet med analysen var at vise, hvordan de faktiske profitproduktionsmetoder var udviklet på værftet, og undersøgelsen viste, at man i en række år udelukkende havde satset på at sikre profitproduktionen gennem intensiveringer, som iøvrigt har givet meget ringe arbejdsforhold. Der havde dog forekommet investeringer i korte perioder; hver gang der var investeret i produktionsanlæg var resultatet en frisættelse af arbejdskraft.

Krisegennemslaget fremtvang modsætningsfuldt nok stigende investeringer i hele værftsindustrien, også på Helsingør Værft. Det hang sammen med, at krisegennemslaget betød en formindskelse af totalprofitmassen, og derfor umiddelbart også en formindskelse i størrelsen af den profitmasse, som værftskapitalerne tilegnede sig af totalprofitmassen. Da værftsbranchens profitrate i forvejen var meget lav, betød krisegennemslaget, at de nødvendige minimums-

58. Vedrørende branche- og enkeltkapitalanalyser se endvidere Stig Wolfsberg, Nils Thorsen, Birgit Land og Vibeke Andersen: Krise i brancheanalysen, brancheanalyse i krisen; Kurasje nr. 25, s. $49-80$. 
profitter ikke længere var sikret. Der var derfor kun en vej, nemlig gennem akkumulation (hvor staten betalte en god del) at hæve profitraten, d.v.s. forøge den andel af totalprofitmassen, som værftskapitalerne, herunder også Helsingør Værft tilegnede sig. For værftsarbejderne betød krisen derfor fyringer. Disse fyringer var imidlertid ikke (selvom det var det almindeligste indtryk) et resultat af braklægning, men en følge af, at krisegennemslaget fremtvang udvikling i arbejdets produktivkraft gennem fixkapitalinvesteringer.

Udfra den tidligere fremførte kritik er det klart, at en forudsætning om parallelitet mellem værdi og pris ikke ville være i stand til at indfange udviklingen på Helsingør Værft. Den ville nemlig føre til en faktisk abstraktion fra konkurrencen, hvad der ville være en meningsløshed, når det drejer sig om undersøgelse af enkeltkapitaler (eller brancher).

I artiklen løses dette problem ved at undersøge udviklingen på to niveauer: totalkapital- og enkeltkapitalniveau, og ved at relatere disse to niveauer til hinanden.

Totalkapitalens bevægelser analyseres kun med henblik på at fastlægge udstrækningen af de forskellige akkumulationsfaser (den extensive, den intensive og krisefasen), og påvise fasernes skranker og de rammer, som de respektive akkumulationsformer sætter for enkeltkapitalernes profitproduktionsmetoder. Totalprofitmassen, totalmerværdimassen og udbytningsgrad behandles ikke emperisk, idet totalkapitalens akkumulationsformer alene fastsættes udfra udviklingen i den organiske sammensætning og væksten i den variable totalkapital henholdsvis den fixe konstante totalkapital. Det er ganske vist en ufuldstændig fastlæggelse af akkumulationsformerne, men tilstrækkeligt til formålet, og med den fordel, at værdi-pris-problemet ikke opstår, idet den organiske sammensætning, m.v. belyses udfra udviklingen i deres anlægsstørrelser - altså i priser. Totalkapitalens bevægelser behandles på basis af en generalisering af udviklingen i den industrielle totalkapital (jvf. det foregående).

Enkeltkapitalen - Helsingør Værft - analyseres udfra kostprisreduktioner, d.v.s. $\varnothing$ konomisering med kapitalanlægets forskellige dele og disse $\varnothing$ konomiseringers indbyrdes sammenhæng, fordi formålet ikke er »at belyse den faktiske størrelse af værftets profitmasse og profitrate, men derimod en analyse af aendringer i profitproduktionen $\ll .59$

Set fra enkeltkapitalens synsvinkel sammenfattes konkurrencens to sider i kostprisen, og fremstår som en tvang til sænkning af kostprisen, d.v.s. som en tvang til økonomisering. Sænkes kostprisen i samme omfang som i den $\varnothing$ vrige branche, fastholdes positionen i forhold til den for branchen gældene markeds-

59. Udviklingen på Helsing $\phi r$ Varft, op.cit., s. 106. 
værdi; sænkes kostprisen i branchen i samme omfang som i den øvrige kapital, fastholdes branchens position i forhold til gennemsnitsprofitraten. Ved at tage udgangspunkt i værftets $\varnothing$ konomiseringer, i dens kostprissænkninger abstrahares der ikke fra konkurrencen, men nok fra dens opdeling på de to former.

Kostprissænkningen analyseres udfra $\emptyset$ konomiseringerne med de enkelte dele af den udlagte kapital og sammenholdes med stoflige ændringer i den umiddelbare produktionsproces, såsom ændringer i arbejdskraftforbruget (intensivering, produktivkraftudvikling, beskæftigelsesvirkning), teknologisk udvikling, lønform, m.v. På basis af værftets økonomiseringsformer og produktionsprocessens stoflige udvikling kan ændringer og udvikling i profitproduktionsmetoderne fastlægges. Udviklingen i profitproduktionsmetoderne sættes dernæst i sammenhæng med løn- og beskæftigelsesforholdenes udvikling.

Ved denne fremgangsmåde i analysen af enkeltkapitalen optræder værdipris-problemet ikke. Det udvendiggjorte forhold mellem værdi og pris i kraft af konkurrencen forudsættes. Udviklingen i værftets profitproduktionsmetoder ses som metoder, hvormed værftet opnår en ikke nærmere specificeret andel af totalprofitmassen. Der beregnes en profitrate for værftet for at sætte dens udvikling i sammenhæng med de tidligere fastlagte profitproduktionsmetoder. Fordi profitraten ikke sammenlignes med andre kapitalers profitrate, men kun med sig selv, opstår problemet vedrørende forskellig omslagstid de forskellige kapitaler imellem ikke. Men på grund af omslagstidsproblemet er den beregnede profitrate dog næppe den faktiske, men den kan anvendes til at vise forskydninger over tid på værftet.

Sammenfattende: med disse to eksempler har vi søgt at vise, hvordan problemet mellem værdi og pris kan løses. Forholdet mellem værdi og pris, mellem merværdi og profit er retteligt et forhold mellem kapitalens produktionsproces og cirkulationsproces. Ved at foretage gyldige abstraktioner i forhold til de aspekter af den konkrete historie, som er til undersøgelse, forsvinder de blokeringer, som det såkaldte transformationsproblem har afstedskommmet.

De to eksempler viser forhåbentlig også noget andet, nemlig at formålet med en realanalyse ikke kan være ordning af det empiriske stof udfra én i forvejen fikseret teori. Formålet må tværtimod en begrebsliggørelse af den konkrete historie; i eksemplerne en begrebsliggørelse af den statslige krisepolitik og af en umiddelbar produktionsprocesses profitproduktionsmetoder. Med et sådant formål forsvinder også den række af beregningstekniske problemer og finesser, som har været karakteristisk for kritik og diskussion af 
»realanalyser $\ll .{ }^{60}$

\section{Afsluttende bemærkninger}

Med henvisning til Korsch's marxismekritik og til den udvikling af marxisme, som har fundet sted i 1960'erne og 1970'erne især på universiteterne, har vi argumenteret for, at udviklingen af en historisk aktuel marxisme forudsætter, at den materialistiske historieopfattelse genetableres - ikke som en række dogmer om den historiske udvikling eller som en generel nøgle for den historiske udvikling, men som en praktisk materialisme, der orienterer sig mod historisk konkrete undersøgelser af de virkelige materielle forhold.

Men det må være en hel marxisme; d.v.s. en marxisme, der med udgangs-

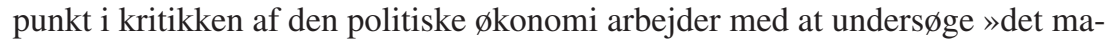
terielle livs produktionsmåde « for at skaffe sig grundlag for at forstå, hvordan de materielle forhold overhovedet betinger »den sociale, politiske og åndelige livsproces «.

60. Det er klart udfra, hvad vi har sagt i det foregående, at kritikken af parallelitetsbetragtningen mindre drejer sig om de prisudtryk, som f.eks. Altvater m.fl. opstiller. Den drejer sig langt mere om den brug, de gør af dem, d.v.s. den måde de fortolker dem på, som igen nøje er forbundet med den status, de tilkender teorien, og den forudsætning, de gør, vedrørende parallelitet mellem værdi og pris; først i anden omgang må kritikken rettes mod beregningerne. Det skal ikke tages op her. 